\title{
Working
}

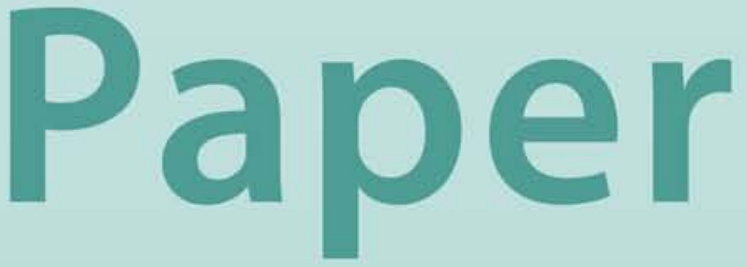




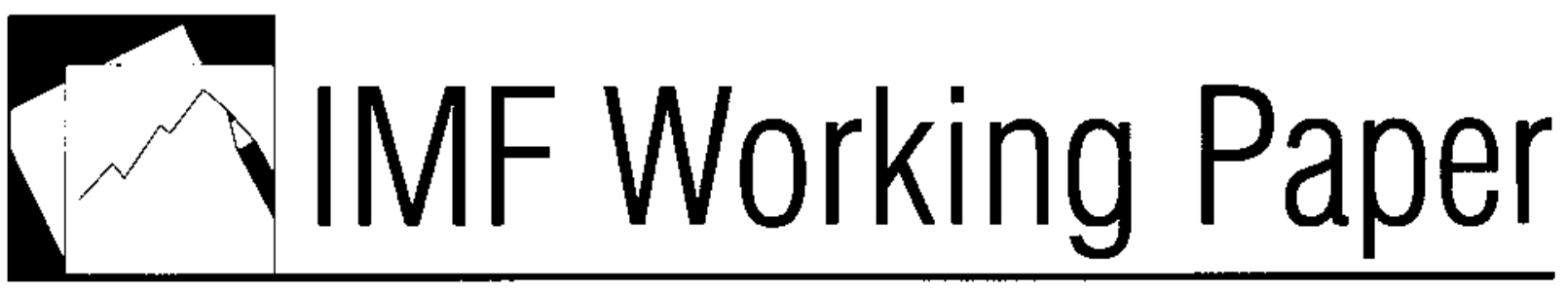

\section{Recession and Policy Transmission to Latin American Tourism: Does Expanded Travel to Cuba Offset Crisis Spillovers?}

Rafael Romeu and Andy Wolfe 


\title{
Recession and Policy Transmission to Latin American Tourism: Does Expanded Travel to Cuba Offset Crisis Spillovers?
}

IMF Working Paper

Western Hemisphere Department

\section{Prepared by Rafael Romeu and Andy Wolfe ${ }^{1}$}

Authorized for distribution by Andy Wolfe

February 2011

\begin{abstract}
This Working Paper should not be reported as representing the views of the IMF. The views expressed herein this Working Paper are those of the authors and should not be attributed to the IMF, its Executive Board, or its management. Working Papers describe research in progress by the authors and are published to elicit comments and to further debate.

This study measures the impact of changing economic conditions in OECD countries on tourist arrivals to countries/destinations in Latin America and the Caribbean. A model of utility maximization across labor, consumption of goods and services at home, and consumption of tourism services across monopolistically competitive destinations abroad is presented. The model yields estimable equations arrivals as a function of OECD economic conditions and the elasticity of substitution across tourist destinations. Estimates suggest median tourism arrivals decline by at least three to five percent in response to a one percent increase in OECD unemployment, even after controlling for declines in OECD consumption and output gaps. Arrivals to individual destination are driven by differing exposure to OECD country groups sharing similar business cycle characteristics. Estimates of the elasticity of substitution suggest that tourism demand is highly price sensitive, and that a variety of costs to delivering tourism services drive market share losses in uncompetitive destinations. One recent cost change, the 2009 easing of restrictions on U.S. travel to Cuba, supported a small (countercyclical) boost to Cuba's arrivals of U.S. non-family travel, as well as a pre-existing surge in family travel (of Cuban origin). Despite the US becoming Cuba's second highest arrival source, Cuban policymakers have significant scope for lowering the relatively high costs of family travel from the United States.

JEL Classification Numbers:F13, F15

Keywords: Cuba, US, Tourism, Caribbean

Author's E-Mail Address:rromeu@imf.org
\end{abstract}

\footnotetext{
${ }^{1}$ International Monetary Fund and the Association for the Study of the Cuban Economy (both authors). We thank Gabriel DiBella and conference participants at the ASCE XIX Annual Meeting and the 2010 International Tourism Convention of the University of Havana for helpful comments and suggestions.
} 


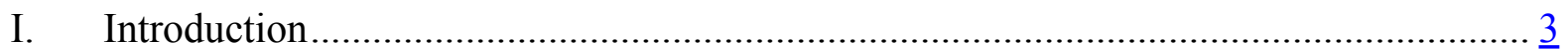

II. An Analytical Framework............................................................................... $\frac{4}{4}$

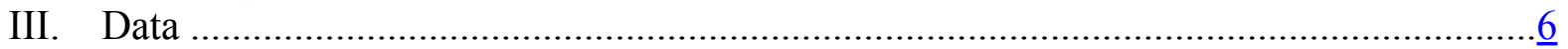

IV. Empirical Results ....................................................................................... $\underline{8}$

V. The Role of Changing U.S. Travel Costs to Cuba ................................................ 11

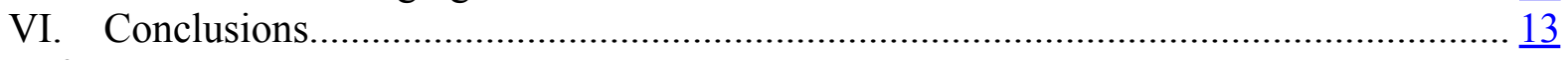

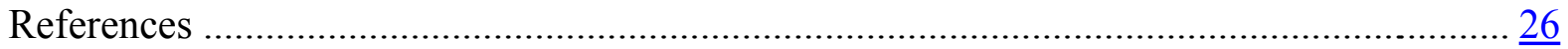

Tables

Table 1. Arrivals by Selected Regions and OECD Groups ............................................. 14

Table 2. OECD Groupings by Labor Market Characteristics........................................... $\frac{15}{16}$

Table 3. OLS Regressions of Tourism Arrivals on OECD Unemployment......................... $\frac{16}{17}$

Table 4. Estimates of the Determinants of Tourist Arrivals ............................................ $\frac{17}{18}$

Table 5. Model Fit of Tourist Arrivals......................................................................... 18

Table 6. Estimates of the Consumer Elasticity of Substitution ....................................... 18

Table 7. Consular Fees for Selected LAC Countries ................................................... 19

Figures

Figure 1. U.S. Unemployment and Tourist Arrivals by Caribbean Country Groups ............ 20

Figure 2. OECD Unemployment Grouped by Labor Market Characteristics ..................... 20

Figure 3. Tests for Unit Roots in Tourist Arrivals ........................................................... $\frac{21}{21}$

Figure 4. OECD Real Wage Changes Against Hotel Price Inflation, 2009 ........................ 22

Figure 5. Arrivals from U.S. and Close Relatives to Cuba, 1990-2009 .............................. 23

Figure 6. Arrivals from Cubans Abroad and the Rest of the World, 2005-09 .................... 23

Figure 7. Income Per-Capita of OECD Countries and Cubans ...................................... 24

Figure 8. Revenue per Tourist, Cuba and Dominican Republic ..................................... $\frac{25}{25}$

Figure 9. Customs Revenue Schedule, Selected Caribbean Countries ................................ 25

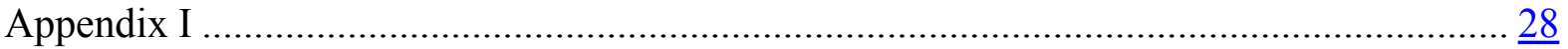




\section{INTRODUCTION}

This study considers the links between recessions in advanced economies and the tourism industry in Latin America and the Caribbean. Tourism is a macro-critical industry for many countries in the region, and in particular, for much of the Caribbean. This study attempts to identify empirically the mechanism that transmits downturns from advanced economies to tourist arrivals in this region, with a view to identifying their size, duration, and available options for policymakers.

A simple model of consumption of tourism services, other goods and services, and labor disutility is presented to structure the empirical analysis. In the model, consumers face a trade-off between consuming tourism services and a basket of other goods, as well as choosing a level of labor (which provides both income and disutility). Having determined the aggregate level of tourism expenditure, consumers then choose how to allocate this tourism expenditure envelope across a number of monopolistically competitive destinations. The model solution identifies the consumer's elasticity of substitution across tourist destinations and yields a general trade determination equation that identifies a role for both domestic and external costs as well as macroeconomic factors in advanced economies in determining the level of tourist arrivals to each destination.

Tests of the model solutions suggest that downturns in advanced economies impact the tourism sector in this region through increases in unemployment, even after controlling for declines in consumption, negative output gaps, and other business cycle indicators. Three empirical results are presented to test both the model's assumptions and its empirical implications.

The trade equation that results from the problem of consumers choosing across monopolistically competitive destinations is estimated. A regression of tourist arrivals (in both log-levels and in percent change) from individual OECD countries to destinations in the Caribbean, Central and South America, is estimated with trade costs as well as endogenous and external factors as explanatory variables. The results suggest that the role of unemployment in driving arrivals is robust to including a battery of trade and other costs, as well as indicators of business cycle conditions in the OECD. The average estimate of the impact of changes in unemployment rates in the OECD on arrivals is approximately four percent, though estimates based on the level of unemployment suggest an even larger impact. The model solution can also forecast arrivals to the region on the basis of forecasted macroeconomic conditions for OECD economies. Based on the available data and holding other factors constant, model projections of the growth in arrivals to each destination suggest a recovery of approximately three to five percent for the Caribbean. The slow recovery is driven by the weak employment outlook for advanced economies as of mid 2010. Analogous projections based on estimates of the level of arrivals for 2010-11 also suggest a potentially weak recovery for the Caribbean of less than 5 percent.

The assumption that shocks to labor income in OECD economies (instrumented by changes in unemployment rates) impact real aggregate expenditure on tourism is also tested. Individual least square regressions of the percent change in each Caribbean destination's aggregate tourist arrivals against the weighted average change in its OECD clients' annual unemployment rates and other factors such as global macroeconomic conditions and natural disasters are estimated. Caribbean destinations are chosen because of both long-term data 
availability of tourist arrivals, and because these are the most tourist-dependent economies in the region. Hence, if the effect is to be found, it must be present there. The estimates support the assumption, as changes in unemployment significantly impact arrivals. Consistent with the trade equation, a one-percent increase in the weighted-average unemployment rate of Caribbean destinations' OECD clients decreases arrivals to that destination by approximately 5 percent.

The model's first-order conditions, which identify the consumer's elasticity of substitution across tourist destinations in the region, are also estimated. The estimates suggest that changes in relative prices are more than offset by changes in market share, i.e., the elasticity of substitution is greater than unity and consistent with the assumption of monopolistic competition. Hence, a destination that is able to lower the costs perceived by its consumers will grow its market share, but not take all the market. This result suggests that productivity improvements that lower prices for consumers bring larger gains in market share and, hence, higher revenues.

Finally, the impact of rising costs on arrivals is estimated using a natural experiment that occurred in Cuba in 2004-09 as travel restrictions (i.e., travel costs) increased for its second largest source of tourists, persons under U.S. jurisdiction. ${ }^{2}$ These costs are found to have significantly negatively impacted travel from the United States to Cuba. Nonetheless, despite their reversal in 2009 by the United States, the evidence suggests that costs for U.S. travel to Cuba are also imposed by the Cuban authorities for Cubans residing abroad (the vast majority of persons under U.S. jurisdiction travelling to Cuba). These costs are high compared with other Caribbean destinations (e.g., Jamaica and the Dominican Republic). Thus, notwithstanding the relaxation of travel restrictions by the United States in 2009, the costs of U.S. travel to Cuba imposed by Cuban authorities are high when compared with similar costs for travel to Jamaica or the Dominican Republic, or other parts of the region. Hence, there exists considerable scope for the Cuban authorities to lend policy support to this macro-critical sector.

The next section presents the model assumptions and gives the estimable equations resulting from its solution, which are presented in detail in an appendix. The second section presents descriptive statistics and empirical estimations of the model conclusions. The fourth section estimates the impact of changing travel costs to Cuba, and the final section concludes.

\section{An AnAlytical FrameWORK}

The section outlines the model that structures the empirical results presented in the next section, and is shown in detail in the appendix. To a large extent, the model combines the monopolistically competitive framework based on Dixit and Stiglitz (1977) preferences and presented in Blanchard and Kiyotaki (1987) (henceforth, BK) with the gravity trade model presentation of Anderson and Van Wincoop (2003) (henceforth, AV). In addition, labor income is assumed to be driven in part by common shocks across groups of OECD countries with similar structural wage determinants. Also, a simple destination specific cost structure is

\footnotetext{
${ }^{2}$ Throughout the study, persons under U.S. jurisdiction are classified consistent with the White House Office of the Press Secretary, April 13, 2009, Fact Sheet: Reaching out to the Cuban People.
} 
assumed, that allows for distinguishing country-specific effects from shocks external to the tourist destinations.

Consider the problem of $j=1$ to $M$ OECD economies' consumers who derive their aggregate utility $(V)$ as the sum of utility from consuming tourism services $(U)$ across $i=1$ to $N$ Caribbean destinations and utility from consuming a composite basket of all other goods the numeraire, denoted $G$ in (1.1). Finally, consumers derive disutility from labor, denoted $\mathrm{N}$ in (1.1). Equation (1.1) gives the utility maximization problem for consumers from OECD country $j$ :

$$
V_{j}=U_{j}^{\gamma} G_{j}^{1-\gamma}-\mathrm{N}_{j}^{\beta}, \quad \text { s.t. } I_{j}-T_{j}-G_{j}=0, \quad I_{j}=W_{j} \mathrm{~N}_{j}+O_{j} .
$$

$\gamma$ is assumed to be between zero and one, and $\beta$ equal to or greater than one, $W_{j}$ is the wage, and $O_{j}$ is all other income. Consumers in OECD country $j$ spend $T_{j}$ on all tourism consumption and pay $p_{i j}$ for tourism in destination $i$, out of total income $I_{j}$, spending the rest on goods, $G_{j}$. The additive separability of labor allows for its marginal disutility to be set to the marginal utility of consuming across all goods (a weighted average of the marginal utility of tourism services consumption and all other consumption). The tradeoff between total tourism consumption and consumption of other goods is optimally set by the relative income shares standard to Cobb-Douglass preferences. Consumers then maximize the subutility function across monopolistically competitive tourism destinations which have some imperfect substitutability, with elasticity of substitution, $\sigma \equiv 1 /(1-\rho)$ :

$$
U_{j}=\left(\sum_{i=1}^{N} C_{i j}^{\rho}\right)^{1 / \rho} \quad 0<\rho<1, \quad \sigma \equiv 1 /(1-\rho), \quad \text { s.t. } T_{j}-\sum_{i=1}^{N} p_{i j} C_{i j}^{\rho}=0
$$

$T_{j}=\gamma I_{j}$ is the optimal level of tourism expenditure by consumers from OECD country $j$, and $I_{j}$ reflects shocks to individual OECD countries' labor and dividend income (e.g., shocks to wages, dividends) that are correlated across OECD groups with similar adjustments in aggregate real wages over the business cycle. Hence:

$$
T_{j}=\gamma I_{j}=\gamma \bar{I}_{g} \hat{I}_{j} \quad \forall j \in g .
$$

In (1.3) $\bar{I}_{g}$ represents the common factor driving income for OECD countries in group $g$, where a group consists of OECD countries with similar wage income processes over the business cycle, and $\hat{I}_{j}$ represents the idiosyncratic component for country $j$. The first-order conditions yield the following well known ratio:

$$
C_{i j}=\left(\frac{p_{i j}}{p_{i k}}\right)^{-\sigma} C_{i k} .
$$

Equation (1.4) is estimated directly in log-linear form to recover the consumer elasticity of substitution across tourist destinations. The base price of tourism in destination $k$ is given by $p_{k}$, the final price paid by consumers is marked up by $t_{k j}$ because of travel costs, trade 
barriers, and other factors. The appendix shows that the value of tourism to destination $i$ from OECD country $j$ is given by:

$$
X_{i j}=\left(T_{j} T_{i} / T_{W}\right)\left(t_{i j} / P_{j} P_{i}\right)^{1-\sigma}
$$

In (1.5), income to destination $i$ is defined as $T_{i}=\sum_{j=1}^{M} p_{i j} C_{i j}^{\rho}=\sum_{j=1}^{M} x_{i j}$ and world tourism income is given by $T_{W}$, and $P_{j}$ and $P_{i}$ are tourism price indices faced by consumers in $j$ and producers in $i$, which are geometric average price indices with weighting parameter $\sigma$ (the elasticity of substitution). Each destination is assumed to face a fixed and a variable cost in delivering tourism services:

$$
\chi\left(C_{i}\right)=f_{i}+m_{i} C_{i}
$$

Firms at each destination $i$ maximize profits, given by:

$$
\pi_{i}=p_{i} C_{i}-w_{i} m_{i} C_{i}-w_{i} f_{i}
$$

Where $w$ captures the factor cost for destination $i$. Incorporating this cost structure along with the income process in (1.3) into (1.5) yields the estimable equation:

$$
C_{i j}=\left(\gamma \bar{I}_{g} \hat{I}_{j} T_{i} / T_{W}\right) t_{i j}^{-\sigma}\left(P_{j} P_{i}\right)^{\sigma-1}\left(\rho / m_{i} w_{i}\right)
$$

In $\log$ form, the estimable equation becomes:

$$
\ln C_{i j}=c+\ln \hat{I}_{j}-(\sigma-1) \ln P_{j}+\ln T_{i}-(\sigma-1) \ln P_{i}-\ln w_{i} m_{i}-\sigma \ln t_{i j}+\gamma \ln \bar{I}_{g} .
$$

Equation (1.9) groups the terms resulting from the log of (1.8) into those reflecting OECD country or tourist destination factors, trade costs, and the common component of OECD country groups' business cycles.

$$
\ln C_{i j}=\alpha_{0}+\alpha_{1} I_{i t}+\alpha_{2} I_{j t}+\alpha_{3} \text { I.trade }_{i}+\alpha_{4} \text { I.cycle }_{t O E C D}+\alpha_{5} \text { I.us.cuba }_{t}+e_{i j t} .
$$

Equation (1.10) shows the estimable form of (1.9), with $I_{i t}$ and $I_{i t}$ reflecting country-year and destination-year indicators, respectively, which capture non-systemic tourism determinants. I.trade represents instruments included in the estimable form of (1.9) intended to capture costs standard in the trade literature, as in Rose (2004), or specific to tourism, as in Romeu (2008). I.cycle reflects business cycle indicators for groups of OECD countries that share aggregate wage income processes. Finally, I.us.cuba reflects instruments that capture the relative changes in trade costs for travel to Cuba by persons under U.S. jurisdiction from policy changes from 2004-09.

\section{DATA}

The data employed in the various estimations of the model's solution include annual bilateral arrivals data from 1995-2009, various measures of trade costs standard to the trade and industry literature such as distance, common language or colonial indicators, measures of 
business cycle conditions for OECD countries, and prices (including hotel costs for estimating the elasticity of substitution).

Summary statistics for the available arrivals data are shown in

Table 1. The left panel of the table presents shares of total arrivals in 2006 by geographic dispersion and the total number of arrivals, and the right panel gives the shares by OECD country group (discussed below). ${ }^{3}$ The averages for each region appear to lend support to distance and size as the gravity model's drivers of trade. South America (which comprises the largest countries measured by either GDP or population) receives the most tourists, followed by the Caribbean, which is the nearest to OECD countries. Moreover, South America receives the largest share of tourists from within its own region, and equal shares from Europe and North America, as it is (broadly) equidistant from these areas.

A testable implication of the model is the dependence of arrivals on unemployment in the tourists' home countries. Figure 1 shows the monthly unemployment rate in the United States against a simple average of tourist arrival indices for three groups of Caribbean countries. This region is a good candidate for observing the link between employment and tourist arrivals as it is highly dependent on U.S. arrivals, and hence the influence of U.S.

unemployment should be most visible in this region. The figure graphs U.S. unemployment against average arrivals of larger Caribbean countries, the Eastern Caribbean Currency Union countries, and the entire Caribbean destinations. Arrivals appear inversely related to the U.S. unemployment rate for all three sub-regional groups.

The empirical form of the model solution given in (1.9) captures the impact of OECD unemployment on tourist arrivals through the common factors driving unemployment dynamics across groups of OECD countries. As indicated in the discussion of equation (1.10), idiosyncratic shocks to individual countries cancel out of the specification. Hence, to identify the common shock to employment, income, and consumption,

\footnotetext{
${ }^{3}$ Summary statistics and model estimates are based on the available bilateral arrivals data, and hence, reported total arrivals are calculated as the sum of arrivals from identified countries, e.g., arrivals from North America are counted to the extent that arrivals from the United States, Canada, and Mexico are reported and figures reported as, for example, from "North America" or "Other North America" are excluded. Argentina is not shown in the table due to limited reporting of arrivals from individual OECD countries. Data is unavailable for recent years, particularly for 2009 , for many source countries.
} 
Table 2 identifies groups of OECD countries with similar unemployment and income dynamics throughout the business cycle. Country groups result from combining hierarchical clusters across: the cyclical and trend components of their unemployment rates, the aggregate wage payments throughout the business cycle, and measures of cultural similarity. The results suggest a first group consisting mainly of the largest OECD economies (United States, United Kingdom, Germany, and Japan), a second group mainly consisting of Southern European countries, and the third, mainly countries not in the first two groups. ${ }^{4}$ In the results presented below, group averages weighted by GDP are employed to capture the common factor driving unemployment, output gaps, and consumption growth for each group. Figure 2 shows the changes in the weighted average trend (left) and observed (right) unemployment rate of advanced economies by these groupings from 1965 to the present (and projected forward based on IMF estimates). While the three groups clearly move together, there are important differences in the observed unemployment, for example, Group 2 shows higher unemployment rates throughout most of this period, with larger swings in unemployment as well. Group 1 shows the lowest unemployment rates, but converges in recent years to the average for Group 3, and also shows larger changes in its trend unemployment rate relative to Group 3. The tests of the model need to show that these differences across OECD groups alongside the varying exposures of tourist destinations to each group drive the differences in tourist arrivals.

One complication in interpreting results based on arrivals data is the potential for nonstationarity, as one could posit that arrivals should grow broadly in line with population growth in OECD countries. We try to limit this concern by employing bilateral arrivals, for which it is less clear that, for example, arrivals from Germany to the Dominican Republic increase broadly in line with population growth in the former. ${ }^{5}$ Figure 3 graphs the average pvalue resulting from testing for stationarity on arrivals to each country in Latin America and the Caribbean from all source countries so show the average of the probabilities of rejecting the null hypothesis that the series of tourist arrivals from each source country contains a unit root. The average p-value for Cayman Islands, for example, fails to reject the presence of a unit root in its arrivals series, while the average $p$-value for Bermuda rejects a unit root at all conventional levels. As the evidence is mixed, the model is estimated on both the log of arrivals and the log-difference of arrivals.

Finally, the first-order conditions allow estimation of the consumer elasticity of substitution across tourist destinations. This parameter captures the willingness of consumers to substitute across destinations as relative prices change, and reflects the sensitivity of consumers to increasing relative costs of visiting different destinations. Figure 4 graphs hotel price changes in 2009 for available destinations in Latin America and the Caribbean against the average

\footnotetext{
${ }^{4}$ These groupings are intended to be broadly consistent Messina, Chiara, and Turunen, (2008), which groups OECD countries based on business cycle variation in wage income, clustering by trend and cyclical unemployment measures as shown in

Table 2, and with Romeu (2008), which groups OECD countries by sociological measures of "Cultural Similarity" to determine tourism preference patterns. Estimates are robust to minor permutations along these groupings.

${ }^{5}$ More concretely, this does not seem to be the case: tourism arrivals from Germany to the Dominican Republic increased by an average of 10 percent annually before 2000, and declined by 10 percent annually after 2000 .
} 
change in the wage of each destination's visitors. The average wage is calculated by taking the real wage indices for each country and converting them to U.S. dollars, and then taking the weighted average of this series (weighted by pre-crisis arrivals). In comparing real wage declines against real prices declines during the crisis, we see two kinds of adjustments occurring during the crisis: price adjustments that destinations made relative to each other and general downward price adjustments made in response to their clients' declining income.

\section{EMPIRICAL RESULTS}

The first test of the model considers whether the data support the assumptions resulting from the tourism expenditure envelope defined in (1.3) and the additive separability of labor income assumed in (1.1). On the basis of these two conditions, the average of business cycle indicators across groups of similar OECD countries are included as drivers of tourism, i.e., the common unemployment shock across groups of OECD countries with similar business cycle characteristics is used to predict tourism. Simple OLS regressions estimate the growth of the number of tourists arriving to Caribbean destinations owing to the change in the weighted average unemployment of the home countries of the arriving tourists (shown in Table 3) and controlling for other factors that also influence tourism arrivals: the change in the real exchange rate, the change in oil prices, the severity of tropical storms affecting each country per year, and an autoregressive error. The regressions are run on annual data from 1980 to the present. The response of arrivals to an increase in the unemployment of its tourists' home countries averages above five percent, across the fifteen countries tested. Moreover, the result for smaller destinations (excluding Aruba, Cuba, Dominican Republic, and Jamaica) is economically of the same size as for the entire sample. A panel regression using the available Caribbean tourist destinations is presented in the last column, and the results suggest that an increase in unemployment in advanced economies lowers arrivals by 3 percent. Hence, the results imply that an average increase in unemployment of one percentage point in the home country of tourists lowers arrivals to the Caribbean by approximately three to 5 percent. The fit of the estimated regressions averages 40 percent across all countries, though there is considerable variation within the sample of countries, so the results need to be seen as a first round of estimations.

Turning to tests of the model itself, estimates of the empirical form in (1.9) are given in Table 4. A panel regression of tourist arrivals from each OECD country to each destination in the Caribbean, Central and South America is estimated using annual data from 1995-2009. The three left columns show regressions using the annual percent growth rate of arrivals for each country-destination pair as the dependent variable. The three right columns show the regression results using the log of arrivals as the dependent variable. The explanatory variables controlling for travel costs include the (great circle) distance between the source and destination countries, and indicators for: common language, historical links, different geographic areas (Central and South America), as well as a time trend. Consistent with prior trade studies, distance is an important inversely-related predictor of bilateral trade, while historical and language links significantly drive trade, as well.

Tourism-industry specific costs are captured with indicators for: Puerto Rico, low-income countries, small Caribbean islands (as discussed above for Table 3), and an indicator for large 
and specialized tourism destinations. ${ }^{6}$ This last indicator is unity if a destination receives more than one million visitors annually after 2000 and if this number of visitors is at least 15 percent of the destination population. ${ }^{7}$ The significant boost to arrivals observed for Puerto Rico observed in prior work also shows up in these results, as does the negative impact on arrivals of very low national income levels. The estimate for large and specialized destinations, which is intended to reflect scale economies, is positive and significant in the arrivals growth regression. This indicates that larger tourism-specialized countries' arrivals grow faster than others in the region, all else equal. The analogous estimate for small islands, however, reflects negative growth in arrivals in only one of two growth regressions. Taken together, these results could be interpreted as reflecting an advantage of larger tourismspecialized destinations over the rest of the LAC region (e.g., arrivals to Uruguay grow faster than arrivals to Brazil), while at the same time, failing to find robust evidence that smaller destinations (e.g., Saba) grow more slowly than regional comparators. Measures intended to reflect changes in U.S.-Cuba travel costs are also included and are significant and signed as expected ( and discussed in the next section).

The GDP-weighted average of the following OECD business cycle indicators are included to capture labor income and consumption shocks: the unemployment rate and the change in unemployment rate, log real GDP, real consumption growth, the gap between observed and trend real consumption, real GDP, and the output gap. The estimated coefficients for the growth regressions are signed as expected, and for unemployment suggest that an increase in the weighted average unemployment rate across groups decreases the growth of arrivals by approximately four percent, after controlling for growth in consumption, short-term consumption gaps, and output gaps. The estimated coefficient on the output gap is also positively signed as expected-economies with positive output gaps increase tourism consumption. On the other hand, there is a negative impact of the consumption gap on tourism suggesting that above-trend OECD consumption does not translate into higher arrivals for the region. This could be interpreted as reflecting low substitutability between consuming tourism services abroad and all other goods and services. The fit of the model along with a short-term projection is presented in Table 5 for South American and Caribbean countries. Comparing across regions, the model predicts better for South America in the noncrisis period (2005-07), whereas it picks up the impact of the crisis more accurately for the Caribbean. The model projects a recovery in the Caribbean of just above 5 percent for the coming year based on IMF forecasts of unemployment, output and consumption.

Turning to the regressions in log-levels, the negative relation between unemployment rates and arrivals is confirmed. The estimated coefficient on unemployment is higher than in the previous regressions, and suggests a greater impact for all three groups. Nonetheless, this coefficient, estimated on the average unemployment across groups, needs to be interpreted with care. A one-standard deviation increase in the average unemployment in Group One (the most important of the three by number of visitors) causes an average decline of between 10-

\footnotetext{
${ }^{6}$ See Rose (2004) on costs common to gravity trade models, and Romeu (2008) for models and estimates that consider costs specific to tourism services trade.

${ }^{7}$ Calculated using available overnight arrivals data, these are: Bahamas, Cancun, Costa Rica, Cuba, Dominican Republic, Jamaica, Puerto Rico, and Uruguay. These criteria are chosen to represent economies of scale.
} 
15 percent in arrivals. Arrivals from Group One are the least sensitive (because it has the lowest standard deviation of average unemployment) followed by Groups Three and Two, respectively. The higher estimated impact from the estimation in log-levels rather than in changes could, to some extent, reflect small sample problems such as insufficient variation in unemployment rates within the sample alongside a long-term decline of the unemployment rate during the sample for some OECD countries. Importantly, fewer observations are available during the recent crisis years because of delayed reporting. These statistical difficulties potentially bias the estimates upwards, as the sharp increases in unemployment from the recent crisis are not fully reflected in these data. These caveats notwithstanding, one should expect the sensitivity to the average of OECD unemployment rates to be high, as an increase in these, particularly in Group One which includes the United States, Japan, and Germany, is likely to signal a broader global slow-down.

As expected, increases in real GDP and consumption growth in the OECD drive tourism higher, independent of the impact from unemployment. The estimated coefficient on the weighted 1-year change in the index of consumption indicates that tourism increases with consumption growth. While the estimate is insignificant at conventional levels, this could reflect the measure of consumption used and the small weight tourism is likely to have within the overall OECD consumption basket. The estimate of the impact of the log-weighted real GDP index is large because the index itself varies very little. One could interpret the result as an approximately 1 percent increase in advanced economy real GDP growth increases arrivals by above 10 percent. The high R-squared is common to studies that estimate gravity trade equations.

Estimates of the consumer elasticity of substitution based on the first-order conditions (equation (1.4)) are presented in Table 6. Based on data availability for 2008-09, the table shows the estimated coefficients on the varying costs that determine arrivals (either constrained to be equal to each other or unconstrained). The estimates provide evidence consistent with the model assumption of monopolistic competition. A destination (or firm) whose costs are 1 percent higher than the rest of the Western Hemisphere - controlling for distance and other determinants - stands to lose between 1.2-1.6 percent of its arrivals.

\section{The Role of Changing U.S. Travel Costs to Cuba}

Policies that alter the restrictions on U.S. travel to Cuba provide a natural experiment for measuring the sensitivity of tourist arrivals to changing costs. The controls for policyinduced travel costs for U.S. travelers to Cuba included in the regression shown in Table 4 reflect the impact of such changes. Costs from long-term restrictions on such travel are captured in the estimated coefficient labeled U.S.-Cuba Travel Costs. Having controlled for the higher long-term cost, the impact on arrivals of "non-family" and "family" travel (or Cubans residing in the United States) from temporarily increasing travel costs starting in 2004 are also measured. ${ }^{8}$ Figure 5 shows that enforcement of these restrictions, largely

\footnotetext{
${ }^{8}$ Official classification of travel to Cuba by U.S. citizens and residents of Cuban origin varies and is termed here "family travel" to distinguish this travel from other U.S. citizens travelling to Cuba. U.S. authorities broadly classify these as persons within three degrees of family relationship with Cubans. The Cuban authorities broadly classify these as Cubans residing abroad and their immigration status and year of departure determines an array of travel costs. The World Tourism Organization classifies these as tourists arriving from the "Other Caribbean."
} 
repealed in 2009 for family travel, were sufficient to impact both family and non-family travel to Cuba. The shaded bars reflect the number of U.S. Treasury Office of Foreign Asset Control (OFAC) penalties imposed for violating regulations limiting travel and trade with Cuba, while the lines show family and non-family arrivals from the United States. ${ }^{9}$ Enforcement during 2003-05 halted family travel for three years and slowed non-family travel largely through $2009 .^{10}$

The estimates in Table 4 of the long-term impact of travel restrictions suggests that unfettered (pre-crisis) non-family U.S. tourist arrivals to Cuba would vary between 3.2 and 4 million annually (from roughly 60,000 at present). The policy enacted from 2004-09 reduced non-family U.S. travel to Cuba significantly (by 80 percent) while for family travel, the sign of the estimated coefficient is negative as expected but insignificant. From Figure 5 one notes that family travel was halted only temporarily, falling in 2003-04, but that the trend growth broadly continued afterwards. This is confirmed in Figure 6, which compares the growth and contribution of growth of arrivals to Cuba from family travel (Cubans residing abroad) and the rest of the world from 2005-09. Family travel pulled up total growth every year and represented one-fourth of total growth in arrivals to Cuba during this five-year period. Non-family U.S. arrivals also increased by 25 percent in 2009, however, this still represents under 3 percent of total arrivals to Cuba. Hence, despite temporarily slowing due to policy changes enacted in 2003-04, family travel from the United States to Cuba has represented one-fourth of the total growth in arrivals to Cuba since 2005.

The policy implication for all tourist destinations from this episode is that enacting changes that lower travel costs is an effective strategy for increasing arrivals. The Cuban authorities are poised to benefit from travel for U.S. visitors (and particularly, family travel) in the wake of the 2009 policy changes. This category of tourist has surpassed that of any individual European country to become the second most important source arriving to Cuba after Canada. Figure 7 shows that income measures for this population (Cubans residing in the United States) is comparable to that of Canada, and there is evidence that family travel has much stronger linkages to the real economy than other types of international tourism. ${ }^{11}$ For example, Figure 8 compares tourism revenue in Cuba with revenue in the Dominican Republic broken down by Dominicans residing abroad and at home and other foreign tourists. During the crisis, Cuba suffered an approximate decline in revenues of 15 percent. The Dominican Republic also observed declining revenue from foreign tourists, though less so, but revenues from Dominicans both at home and abroad increased and appears to be countercyclical. Hence, setting aside the potential windfall from non-family U.S. travel, Cuba's current second largest source of tourists is now facing lower travel costs and has

\footnotetext{
${ }^{9}$ Data as reported by the Congressional Research Service and the U.S. Treasury OFAC. The U.S. GAO shows a graph that is consistent with Figure 5, however it does not release data detailing their study of November 2007 on OFAC enforcement. Pre-2003 data is not publicly available from the U.S. Treasury website, see Sullivan (2009).

${ }^{10}$ The current U.S. administration announced a lift on all restrictions on family visits. See "Fact sheet: Reaching Out to the Cuban People," Office of the Press Secretary, The White House, April 13, 2009.

${ }^{11}$ See Diaz-Briquets (2001), Henken (2000), and Padilla (2003) on backward linkages.
} 
relatively high income and strong backward linkages to the real economy, and thus, could potentially be a countercyclical income source.

In view of the potential benefits of countercyclical income sources, there appear to be a number of policy options available to the Cuban authorities to lower family travel costs. Table 7, for example, compares bureaucratic costs such as passports, required for family travel to Cuba with those for other countries in Latin America. These costs in the case of Cuba are five to ten times those in other countries. Figure 9 compares customs duties on imports. These are also much higher in Cuba than in neighboring Jamaica or Dominican Republic.

\section{CONCLUSIONS}

This study models and estimates the impact of advanced economy business cycle conditions on the tourism industry in Latin America and the Caribbean. A simple model of labor, consumption of both tourism across monopolistically competitive destinations and of a basket of all other goods and services, is presented to structure the analysis. The model suggest that consumption growth, output gaps, and labor conditions in advanced economies will all impact tourist arrivals to Latin America and the Caribbean.

The estimates presented support the model's conclusions and suggest that tourism is dependent on employment conditions in advanced economies, and that the industry is monopolistically competitive. Estimates presented suggest that a one-percent increase in advanced economy unemployment lowers tourist arrivals by 5 percent, even after controlling for important domestic and external drivers of tourism, including industry and trade costs, recessions, and changes in consumption growth. The estimates presented also suggest that a 1 percent decline in the cost of tourism services is found to increase arrivals by $1.2-$ 1.6 percent; thus a marginal decline in tourism prices is more than offset by the resulting increase in arrivals, and hence, revenues increase, all else equal.

The impact of a natural experiment resulting from policy driven changes in travel costs from the United States to Cuba is also estimated. The results suggest that for Cuba, the loosening of travel restrictions in 2009 helped offset the decline in arrivals from the global financial crisis - a potentially significant external countercyclical source of growth. Capitalizing fully on this countercyclical external demand would suggest revising policies to lower travel costs for persons under U.S. jurisdiction traveling to Cuba, and in particular "family" travel, which are currently a multiple of the costs to travel elsewhere in the region. 
Table 1. Arrivals by Selected Regions and OECD Groups

\begin{tabular}{|c|c|c|c|c|c|c|c|c|c|c|}
\hline \multirow[b]{2}{*}{ Central America } & \multirow[t]{2}{*}{ North Amer. } & \multirow[t]{2}{*}{ Europe } & \multirow{2}{*}{$\begin{array}{l}\text { South } \\
\text { Amer. }\end{array}$} & \multirow[t]{2}{*}{ Carib. } & \multirow[t]{2}{*}{ Asia } & \multirow[t]{2}{*}{ Total } & \multicolumn{4}{|c|}{ OECD Groups } \\
\hline & & & & & & & Total & 1 & 2 & 3 \\
\hline Belize & 85.8 & 13.9 & $\ldots$ & 0.3 & $\ldots$ & 201,583 & 96.7 & 84.9 & 8.9 & 6.2 \\
\hline Costa Rica & 72.3 & 18.7 & 7.5 & 0.9 & 0.6 & $1,211,542$ & 86.3 & 76.7 & 13.2 & 10.0 \\
\hline El Salvador & 86.6 & 7.3 & 5.3 & 0.6 & 0.2 & 171,603 & 87.1 & 86.2 & 11.8 & 1.9 \\
\hline Guatemala & 67.8 & 22.2 & 7.5 & 0.8 & 1.6 & 664,202 & 78.0 & 74.2 & 12.1 & 13.8 \\
\hline Honduras & 73.4 & 17.3 & 5.9 & 1.7 & 1.7 & 355,589 & 85.3 & 81.3 & 8.4 & 10.4 \\
\hline Nicaragua & 69.2 & 20.6 & 5.7 & 1.1 & 3.4 & 281,990 & 85.8 & 76.5 & 13.4 & 10.1 \\
\hline Panama & 42.7 & 9.4 & 41.2 & 6.5 & 0.2 & 596,538 & 46.6 & 75.1 & 15.8 & 9.1 \\
\hline Weighted Average of Shares & 67.7 & 16.9 & 13.2 & 1.9 & 1.1 & $3,483,047$ & 78.4 & 60.7 & 9.9 & 7.8 \\
\hline \multicolumn{11}{|l|}{ South America } \\
\hline Brazil & 18.4 & 41.2 & 38.9 & 0.2 & 1.3 & $4,640,406$ & 58.8 & 45.5 & 22.7 & 31.8 \\
\hline Chile & 12.9 & 18.1 & 67.3 & 0.3 & 1.4 & $2,159,513$ & 30.4 & 51.3 & 23.9 & 24.8 \\
\hline Colombia & 44.0 & 1.1 & 51.7 & 2.1 & 1.1 & 767,579 & 38.4 & 89.3 & 10.7 & 0.0 \\
\hline Ecuador & 30.9 & 16.4 & 52.7 & $\ldots$ & $\ldots$ & 747,305 & 47.0 & 71.2 & 17.1 & 11.8 \\
\hline Paraguay & 4.0 & 5.5 & 90.5 & $\ldots$ & $\ldots$ & 153,489 & 9.1 & 36.7 & 33.3 & 30.0 \\
\hline Peru & 24.1 & 21.9 & 52.3 & 0.3 & 1.3 & $1,514,019$ & 45.6 & 62.8 & 19.7 & 17.5 \\
\hline Uruguay & 5.8 & 8.0 & 86.2 & $\ldots$ & $\ldots$ & $1,494,905$ & 13.2 & 48.6 & 26.7 & 24.7 \\
\hline Venezuela & 19.0 & 42.2 & 31.1 & 6.2 & 1.6 & 710,563 & 57.2 & 38.0 & 28.9 & 33.1 \\
\hline Weighted Average of Shares & 18.8 & 26.2 & 53.2 & 0.8 & 1.4 & $12,188,053$ & 43.8 & 23.2 & 9.8 & 10.8 \\
\hline \multicolumn{11}{|l|}{ The Caribbean } \\
\hline Anguilla & 87.0 & 11.4 & $\ldots$ & 1.6 & $\ldots$ & 53,420 & 98.4 & 93.8 & 3.8 & 2.5 \\
\hline Antigua \& Barbuda & 39.1 & 47.2 & $\ldots$ & 13.7 & $\ldots$ & 213,677 & 86.3 & 90.0 & 5.5 & 4.5 \\
\hline Aruba & 75.9 & 8.8 & 12.0 & 3.4 & $\ldots$ & 681,392 & 84.4 & 87.6 & 4.2 & 8.2 \\
\hline Bahamas & 93.0 & 5.2 & 0.5 & 1.2 & 0.1 & $1,565,095$ & 97.8 & 92.6 & 6.0 & 1.4 \\
\hline Barbados & 32.6 & 43.6 & 0.5 & 23.1 & 0.2 & 553,080 & 75.9 & 83.3 & 13.4 & 3.2 \\
\hline Bermuda & 89.0 & 11.0 & $\ldots$ & $\ldots$ & $\ldots$ & 286,930 & 100.2 & 89.2 & 9.8 & 1.0 \\
\hline Cayman Islands & 88.4 & 6.7 & 0.4 & 4.3 & 0.2 & 263,330 & 95.0 & 92.1 & 6.7 & 1.1 \\
\hline Cuba & 41.7 & 46.7 & 8.6 & 1.3 & 1.6 & $2,152,031$ & 80.5 & 30.4 & 48.4 & 21.3 \\
\hline Curaçao & 24.6 & 45.1 & 14.2 & 16.2 & $\ldots$ & 223,296 & $69.6^{\prime}$ & $34.8^{\prime \prime}$ & $5.5^{\prime \prime}$ & 59.7 \\
\hline Cancun & 75.7 & 22.3 & 1.1 & 0.5 & 0.4 & $3,528,600$ & 97.6 & 72.8 & 18.9 & 8.3 \\
\hline Dominica & 29.6 & 13.4 & 0.6 & 56.1 & 0.3 & 83,013 & 43.0 & 82.4 & 7.8 & 9.8 \\
\hline Dominican Republic & 49.8 & 41.6 & 3.5 & 5.1 & 0.0 & $3,266,262$ & 90.7 & 52.5 & 27.5 & 20.0 \\
\hline Grenada & 34.6 & 33.3 & 1.1 & 31.0 & $\ldots$ & 96,952 & 68.0 & 83.2 & 10.5 & 6.2 \\
\hline Jamaica & 81.0 & 15.3 & 0.3 & 3.2 & 0.1 & $1,662,118$ & 96.2 & 86.9 & 10.4 & 2.6 \\
\hline Martinique & 2.1 & 86.4 & 0.6 & 10.9 & $\ldots$ & 471,241 & 88.5 & 1.9 & 1.1 & 96.9 \\
\hline Montserrat & 52.3 & 47.7 & $\ldots$ & $\ldots$ & $\ldots$ & 4,867 & 100.0 & 91.9 & 8.1 & 0.0 \\
\hline Puerto Rico & 96.0 & 2.2 & 0.8 & 1.0 & 0.1 & $1,395,643$ & 97.4 & 97.2 & 2.2 & 0.6 \\
\hline Saint Eustatius & 35.2 & 55.5 & $\ldots$ & 9.4 & $\ldots$ & 6,668 & 90.6 & 37.6 & 2.3 & 60.1 \\
\hline Saint Kitts \& Nevis & 88.5 & 11.5 & $\ldots$ & $\ldots$ & $\ldots$ & 96,865 & 100.0 & 91.6 & 8.4 & 0.0 \\
\hline Saint Lucia & 62.9 & 37.1 & $\ldots$ & $\ldots$ & $\ldots$ & 214,586 & 100.0 & 90.1 & 8.2 & 1.8 \\
\hline Saint Maarten & 70.5 & 21.5 & 1.5 & 6.5 & $\ldots$ & 392,411 & 91.9 & 68.2 & 8.5 & 23.3 \\
\hline Saint Vincent \& Grenadines & 40.4 & 23.8 & $\ldots$ & 35.8 & $\ldots$ & 87,034 & 64.2 & 79.4 & 12.5 & 8.1 \\
\hline Trinidad \& Tobago & 60.3 & 0.8 & 4.1 & 34.2 & 0.6 & 367,573 & 60.7 & 76.8 & 22.5 & 0.6 \\
\hline Turks \& Caicos Islands & 100.0 & $\ldots$ & $\ldots$ & $\ldots$ & $\ldots$ & 199,464 & 100.0 & 85.1 & 14.9 & 0.0 \\
\hline United States Virgin Islands & 92.4 & 2.1 & 0.2 & 5.3 & $\ldots$ & 661,569 & 94.5 & 97.2 & 0.9 & 1.8 \\
\hline Weighted Average of Shares & 66.6 & 25.9 & 2.9 & 4.9 & 0.4 & $18,527,117$ & 91.0 & 63.6 & 16.2 & 11.3 \\
\hline Average All & 49.7 & 25.1 & 21.9 & 3.1 & 0.8 & $34,198,217$ & 72.9 & 48.9 & 13.3 & 10.8 \\
\hline
\end{tabular}

Sources: WTO, CTO, IMF, and Country authorities.

Note: The left panel of the table presents shares of total arrivals in 2006 by geographic dispersion. The right panel shows the share of total arrivals covered by the three OECD country business cycle groupings, as a percent of total and shares of each group. Weighted averages are presented for shares, and the sum is presented for subregions. All calculations based on bilateral arrivals from individual countries (i.e., excludes arrivals in cases where a specific country of origin is unreported). Argentina is not shown due to limited reporting of bilateral OECD arrivals. 
Table 2. OECD Groupings by Labor Market Characteristics

\begin{tabular}{|c|c|c|c|}
\hline & & Country & Group \\
\hline $\begin{array}{l}\text { AUSTRALIA } \\
\text { CANADA }\end{array}$ & & Germany & $\overline{1}$ \\
\hline USA & & Japan & 1 \\
\hline OTH CARIBBE & & United Kingdom & 1 \\
\hline UK & & United States & 1 \\
\hline AUSTRIA - & & Cubans abroad & 1 \\
\hline JAPAN - & & Australia & 2 \\
\hline FRANCE - & h & Canada & 2 \\
\hline SWITZERLAND - & 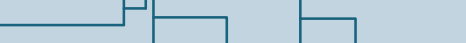 & Greece & 2 \\
\hline ITALY - & & Ireland & 2 \\
\hline BELGIUM - & & New Zealand & 2 \\
\hline GERMANY - & & Portugal & 2 \\
\hline NETHERLANDS - & & Spain & 2 \\
\hline GREECE - & & Austria & 3 \\
\hline DENMARK - & & Belgium & 3 \\
\hline NORWAY - & & Denmark & 3 \\
\hline NEW ZEALAND - & & Finland & 3 \\
\hline PORTUGAL - & & France & 3 \\
\hline FINLAND - & & Italy & 3 \\
\hline SWEDEN - & & Netherlands & 3 \\
\hline IRELAND - & - & Norway & 3 \\
\hline SPAIN - & OECD Unemployment Similarity & Sweden & 3 \\
\hline & & Switzerland & 3 \\
\hline
\end{tabular}

Sources: OECD, and IMF.

Note: Clustering measures of cyclicality adjusted unemployment (left, dendrogram) combined with measures of changes in aggregate wage income yields the three groups (right) of OECD countries assumed to have sufficiently different common components so that their impact on tourism is measured separately in regressions. 
Table 3. OLS Regressions of Tourism Arrivals on OECD Unemployment

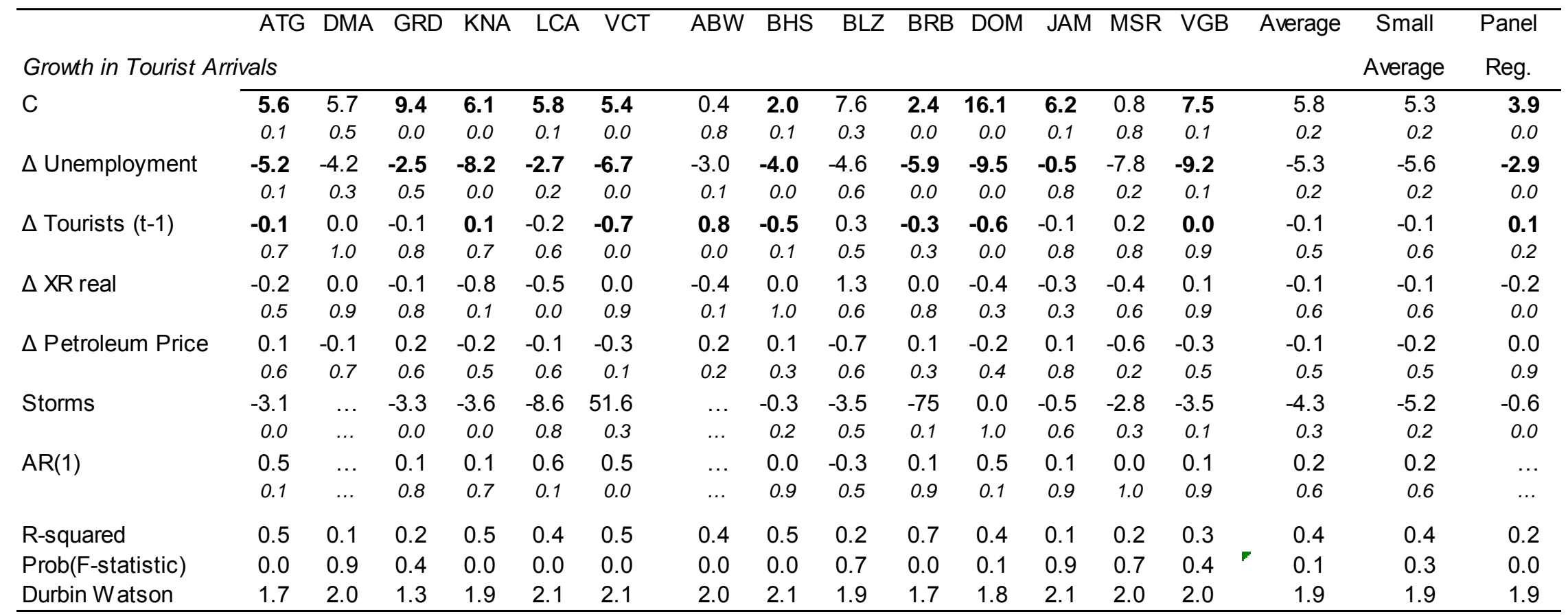

Sources: Caribbean Tourism Organization, Country authorities, Haver Analytics, IMF, and authors' estimates.

Note: The table shows estimated coefficients (and associated p-value, below, in italics) which results from individual country regressions of the growth of tourist arrivals on the following explanatory variables: the change in the weighted average unemployment rate of OECD client countries, the change in the real exchange rate, the change in the oil price, a variable that reflects the severity of tropical storms affecting each country per year, and an autoregressive error. Annual data, 1980-2010, least squares regression. Country abbreviations: Antigua (ATG), Dominica (DMA), Grenada (GRD), St. Kitts \& Nevis (KNA), St. Vincent (VCT), Aruba (ABW), Bahamas (BHS), Belize (BLZ), Dom. Rep. (DOM), Jamaica (JAM), Montserrat (MSR), British Vir. Isl. (VGB). Small excludes ABW, DOM, and JAM. A panel regression (right column), includes Cuba, Cancun. 
Table 4. Estimates of the Determinants of Tourist Arrivals

\begin{tabular}{|c|c|c|c|c|c|c|}
\hline \multirow[b]{2}{*}{ Constant } & \multicolumn{3}{|c|}{$\Delta \ln$ (arrivals) } & \multicolumn{3}{|c|}{ In(arrivals) } \\
\hline & -61.36 & 56.35 & -424.37 & 21.81 & 19.84 & 24.57 \\
\hline Distance & $-15.15^{\star * *}$ & $-21.07^{* \star *}$ & $-21.82^{* * *}$ & $-1.82^{\star * *}$ & $-1.83^{* * *}$ & $-1.80^{* * *}$ \\
\hline Lagged arrivals growth & $-0.16^{\star * *}$ & $-0.15^{\star * *}$ & $-0.15^{\star * *}$ & & & \\
\hline Lagged log-arrivals & $-7.12^{\star \star \star}$ & $-7.97^{\star \star \star}$ & $-8.06^{\star * \star}$ & & & \\
\hline Common language & $12.02^{* * *}$ & $13.17^{* * *}$ & $13.49^{\star * *}$ & $1.25^{\star \star \star}$ & $1.26^{\star * \star}$ & $1.24^{\star \star *}$ \\
\hline Historical Link & $9.04^{\star \star *}$ & $9.88^{* * *}$ & $9.59^{* \star *}$ & $1.06^{* * *}$ & $1.06^{\star * *}$ & $1.06^{\star * *}$ \\
\hline U.S.-Cuba Travel Costs & & $-22.95^{\star * \star}$ & $-25.31^{* * *}$ & $-3.70^{* * *}$ & $-3.79^{* * *}$ & $-3.48^{* * *}$ \\
\hline Puerto Rico & & $27.13^{\star * *}$ & $28.11^{* * *}$ & $3.20^{* * *}$ & $3.15^{\star * *}$ & $3.20^{* * *}$ \\
\hline Low income economies & & & & -1.02 & -0.73 & -1.02 \\
\hline Restrict 2004, Cubans abroad & & & & & & -0.14 \\
\hline Restrict 2004, U.S. & & $-40.61^{* * *}$ & $-45.37^{* * *}$ & & & $-0.81^{* * *}$ \\
\hline Large and Tourism Intensive & & $57.03^{* * *}$ & & & $0.95^{*}$ & \\
\hline Trend & 0.01 & -0.03 & 0.22 & & & \\
\hline Small Caribbean Islands & & 7.01 & & & & \\
\hline Indicator, Central America & -8.49 & -8.83 & & $-3.07^{* * *}$ & $-2.81^{\star \star \star}$ & $-3.02^{* \star \star}$ \\
\hline Indicator, South America & $-8.96^{* *}$ & $-8.79^{\star *}$ & & -0.34 & -0.06 & 0.34 \\
\hline Unemployment Rate & & & & $-0.25^{\star \star \star}$ & $-0.25^{\star \star \star}$ & $-0.26^{\star \star \star}$ \\
\hline Real GDP & & & & 0.76 & 1.14 & 0.12 \\
\hline Consumption Growth & & & & 4.18 & 5.38 & 3.62 \\
\hline$\Delta$ Unemployment (in percent) & $-3.60 * \star *$ & $-3.53^{\star * *}$ & $-4.01^{\star *}$ & & & \\
\hline Short-term consumption gap & $-4.80^{\star * *}$ & $-4.84^{* * *}$ & $-7.59^{* * *}$ & & & \\
\hline Real Consumption Index & 34 & $36.12^{*}$ & 29 & & & \\
\hline Short-term output gap & 1.40 & 1.51 & $3.21^{* *}$ & & & \\
\hline $\mathrm{N}$ & 5833 & 5833 & 5460 & 7314 & 7314 & 7314 \\
\hline $\mathrm{R}^{2}$ & 0.10 & 0.10 & 0.11 & 0.85 & 0.86 & 0.85 \\
\hline $\mathrm{R}^{2}$ Adjusted & 0.09 & 0.09 & 0.09 & 0.84 & 0.84 & 0.84 \\
\hline
\end{tabular}

Sources: Country authorities, CTO, Haver, IMF, WTO, and authors' estimates.

Note: The results of a panel regression of log tourist arrivals (and percent changes in arrivals) from OECD to destination countries in the Caribbean, Central and South America is presented, with explanatory variables: great circle distance nautical miles, common language and historical link indicators, an indicator for U.S.-Cuba Travel Costs, a Puerto Rico and low income indicator, and OECD business cycle indicators include: weighted unemployment rate, log-weighted real GDP, Weighted 1-year observed consumption growth. These OECD business cycle indicators are averaged across the three OECD country groups weighted by U.S. dollar GDP. Indicators for U.S.-Cuba travel restrictions in 2004 are included for Cubans residing abroad and U.S. citizens travelling to Cuba. Significance: ${ }^{* *}=0.01 ;{ }^{* *}=0.05 ;^{*}=0.1$. Panel effects least squares estimation with HuberWhite robust standard errors, country-year dummies not presented. Annual data for 1995-2009. 
Table 5. Model Fit of Tourist Arrivals

\begin{tabular}{rrrrrrr}
\hline & \multicolumn{3}{c}{ South America } & \multicolumn{3}{c}{ Caribbean } \\
\cline { 2 - 7 } & Fitted Model & Avail. & \multicolumn{2}{c}{ Fitted Model } & Avail. \\
& Model & Avgs. & Data & Model & Avgs. & Data \\
Avg. 2005-07 & 6.4 & 7.1 & 4.6 & 1.5 & 3.1 & 6.6 \\
2008 & -3.1 & 1.6 & -0.5 & 0.7 & 2.6 & 3.1 \\
2009 & -4.1 & -0.5 & -1.0 & -2.5 & -1.5 & -2.3
\end{tabular}

Memo: Caribbean Recovery 2010/11 proj. 5.3-5.6 percent. Source: Authors' estimates.

Note: the fit of both the first model and a simple average of all models estimated on percent changes in arrivals is compared against the actual growth in arrivals for available data through 2009 for South America and the Caribbean. The fitted model is used to project the short-term recovery in arrivals to the Caribbean on the basis of IMF forecasts for unemployment, consumption and real GDP growth and presented as a memo item. Central America is excluded because of data limitations.

Table 6. Estimates of the Consumer Elasticity of Substitution

\begin{tabular}{|c|c|c|c|c|c|}
\hline \multirow[b]{2}{*}{ Price, destination 1} & \multirow{2}{*}{$\begin{array}{c}\text { Unconstrained } \\
-0.93\end{array}$} & \multicolumn{4}{|c|}{ Constrained } \\
\hline & & $-1.42 * * *$ & $-1.19 * * *$ & $-1.56 * * *$ & $-1.27^{* * *}$ \\
\hline Price, destination 2 & $1.67^{* * *}$ & $1.42 * * *$ & $1.19 * * *$ & $1.56 * * *$ & $1.27 * * *$ \\
\hline Arrivals, destination 2 & $0.56 * * *$ & $0.57^{* * *}$ & $0.54^{* * *}$ & $0.56 * * *$ & $0.54 * * *$ \\
\hline Distance to destination 1 & $-1.39 * * *$ & $-1.42 * * *$ & $-1.19 * * *$ & $-1.56 * * *$ & $-1.27 * * *$ \\
\hline Distance to destination 2 & $1.11^{* *}$ & $1.42^{* * *}$ & $1.19 * * *$ & $1.56^{* * *}$ & $1.27^{* * *}$ \\
\hline Common language with 1 & $\ldots$ & $\ldots$ & $-1.19 * * *$ & $\ldots$ & $-1.27^{* * *}$ \\
\hline Common language with 2 & $\ldots$ & $\ldots$ & $1.19 * * *$ & $\ldots$ & $1.27^{* * *}$ \\
\hline Constant & 3.68 & $5.17^{* * *}$ & $5.38^{* * *}$ & $5.23 * * *$ & $5.45^{* * *}$ \\
\hline $\mathrm{N}$ & 970 & 970 & 970 & 730 & 730 \\
\hline R2 & 0.39 & & & & \\
\hline R2 Ajust. & 0.39 & & & & \\
\hline P-val $H_{0}:\left(\alpha_{P 1}=-1\right)$ & 0.57 & 0.31 & 0.61 & 0.19 & 0.50 \\
\hline
\end{tabular}

Sources: Country authorities, CTO, Haver, Hotels.com, IMF, and authors' estimates.

Note: The results of unconstrained and constrained regression of the consumer elasticity of substitution across tourist destinations in selected countries based on data availability. In addition to average destination hotel price, other travel costs are proxied by common language and distance from each OECD country to each destination. The probability of rejecting the null hypothesis of unit elasticity is presented at the bottom. Significance of the estimated parameters is indicated by: ${ }^{* * *}=0.01 ;{ }^{* *}=0.05 ;{ }^{*}=0.1$ and based on bootstrapped standard errors. Annual data for 2008-2009, with both price and arrivals data available for: Aruba, Bahamas, Barbados, Bermuda, Brazil, Costa Rica, Cuba, Dominican Republic, Ecuador, Jamaica, Peru, Saint Kitts and Nevis, Saint Lucia, U.S. Virgin Islands. 
Table 7. Consular Fees for Selected LAC Countries

\begin{tabular}{|c|c|c|c|c|}
\hline \multirow[b]{3}{*}{ Cuba } & \multicolumn{3}{|c|}{ Passport costs } & \multirow{2}{*}{$\begin{array}{c}\text { Minor } \\
\text { Consent }\end{array}$} \\
\hline & Total & Years valid & Annual & \\
\hline & 670 & 6 & 112 & 150 \\
\hline Argentina & 60 & 5 & 12 & 50 \\
\hline Bolivia & 85 & 6 & 14 & 9 \\
\hline Brazil & 80 & 5 & 16 & 40 \\
\hline Chile & 103 & 5 & 21 & 25 \\
\hline Colombia & 117 & 10 & 12 & $\ldots$ \\
\hline Costa Rica & 31 & 6 & 5 & $\ldots$ \\
\hline Dominican Republic & 60 & 6 & 10 & 35 \\
\hline Ecuador & 110 & 6 & 18 & 20 \\
\hline El Salvador & 60 & 5 & 12 & 20 \\
\hline Guatemala & 65 & 5 & 13 & $\ldots$ \\
\hline Honduras & 75 & 10 & 8 & $\ldots$ \\
\hline Mexico & 101 & 6 & 1 & 0 \\
\hline Nicaragua & 50 & 5 & 10 & 25 \\
\hline Panama & 54 & 5 & 10 & $\ldots$ \\
\hline Peru & 35 & 5 & 7 & 20 \\
\hline Uruguay & 84 & 5 & 17 & $\ldots$ \\
\hline Venezuela, B.R. & 80 & 5 & 16 & $\ldots$ \\
\hline
\end{tabular}

Source: Diaz-Briquets (2010).

Note: Compares passport consular fees, years of validity and annual costs, as well as consent decree fee for minors to travel abroad, by country, rounded to the nearest dollar, in current U.S. dollars. For some countries, the annual cost is lower if requested for a longer time period. For Cuba, the total passport cost includes a consular re-habilitation fee in the third and fifth year after issuance. 
Figure 1. U.S. Unemployment and Tourist Arrivals by Caribbean Country Groups

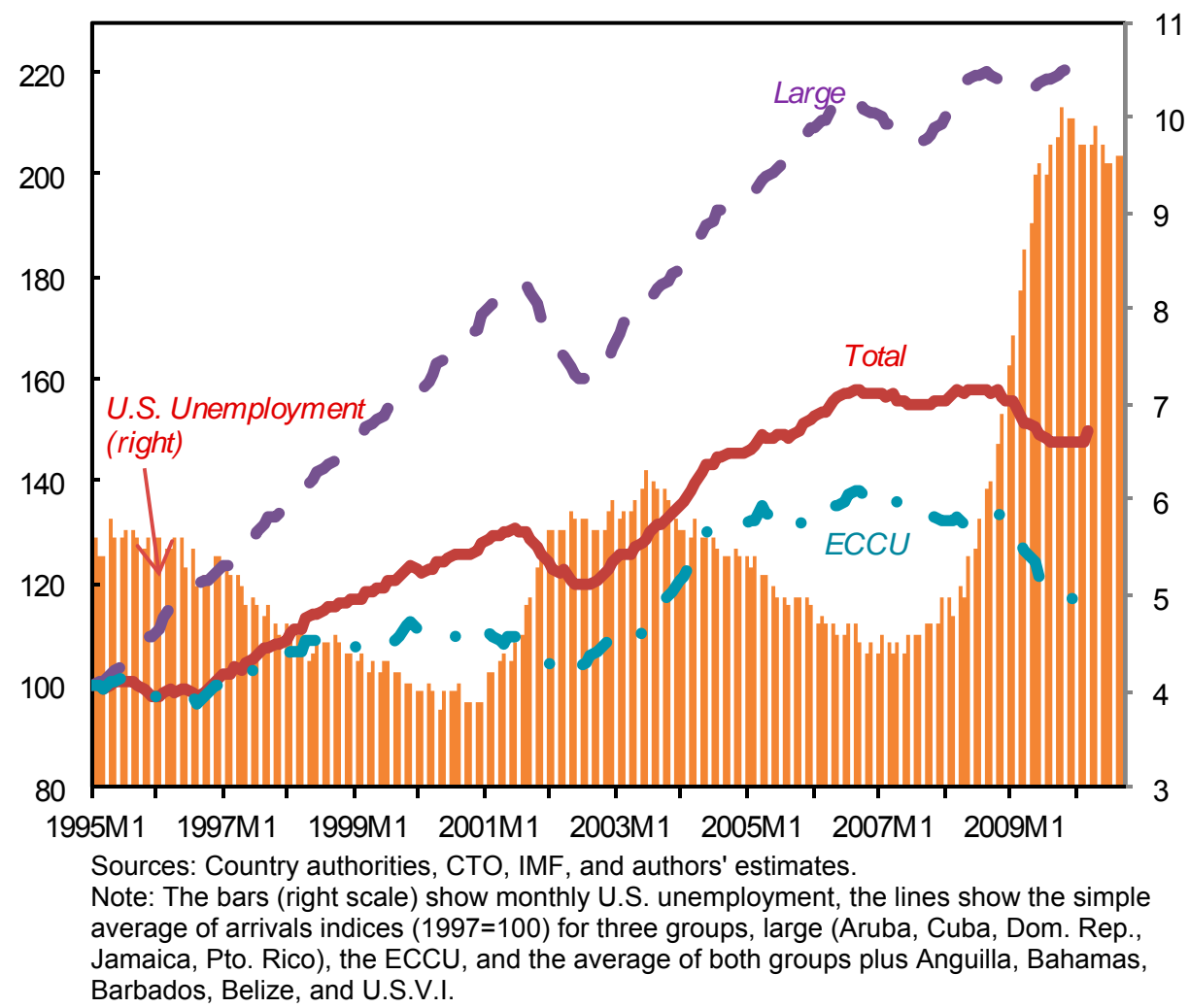

Figure 2. OECD Unemployment Grouped by Labor Market Characteristics
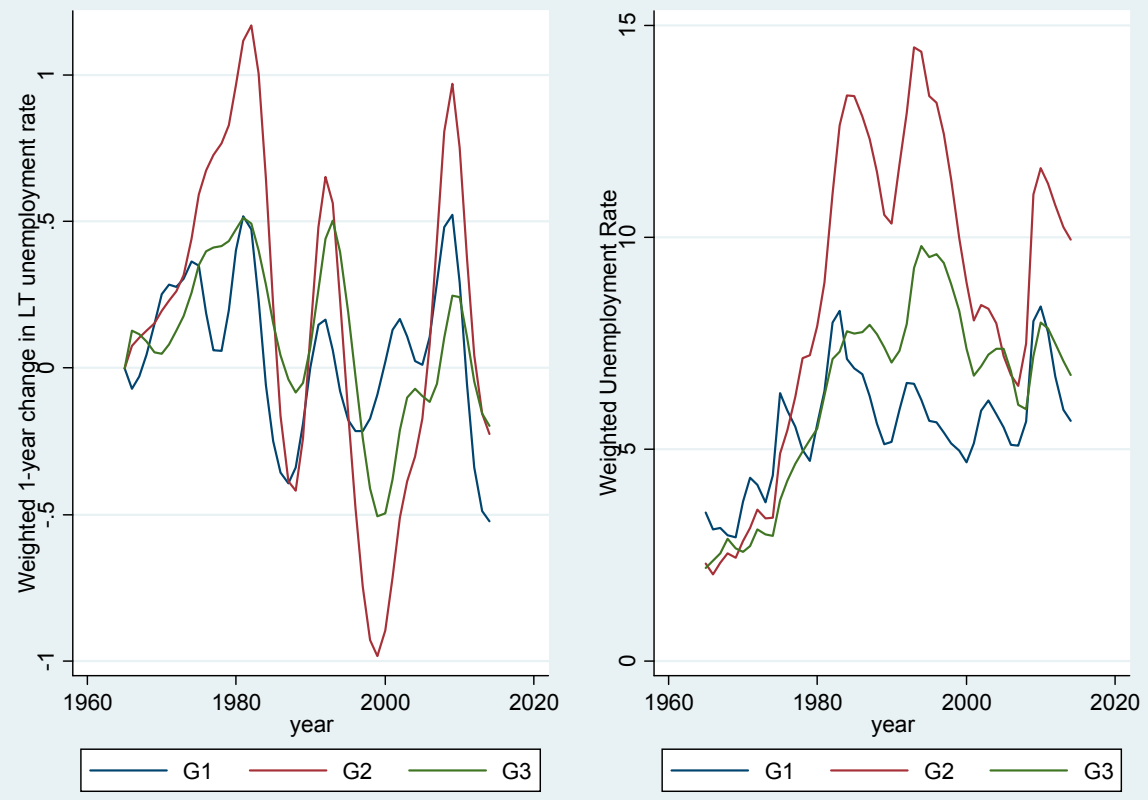

Source:

IMF.

Note: The left panel shows the changes in weighted average advanced economies trend unemployment by groupings. The right shows their weighted average observed unemployment. 
Figure 3. Tests for Unit Roots in Tourist Arrivals

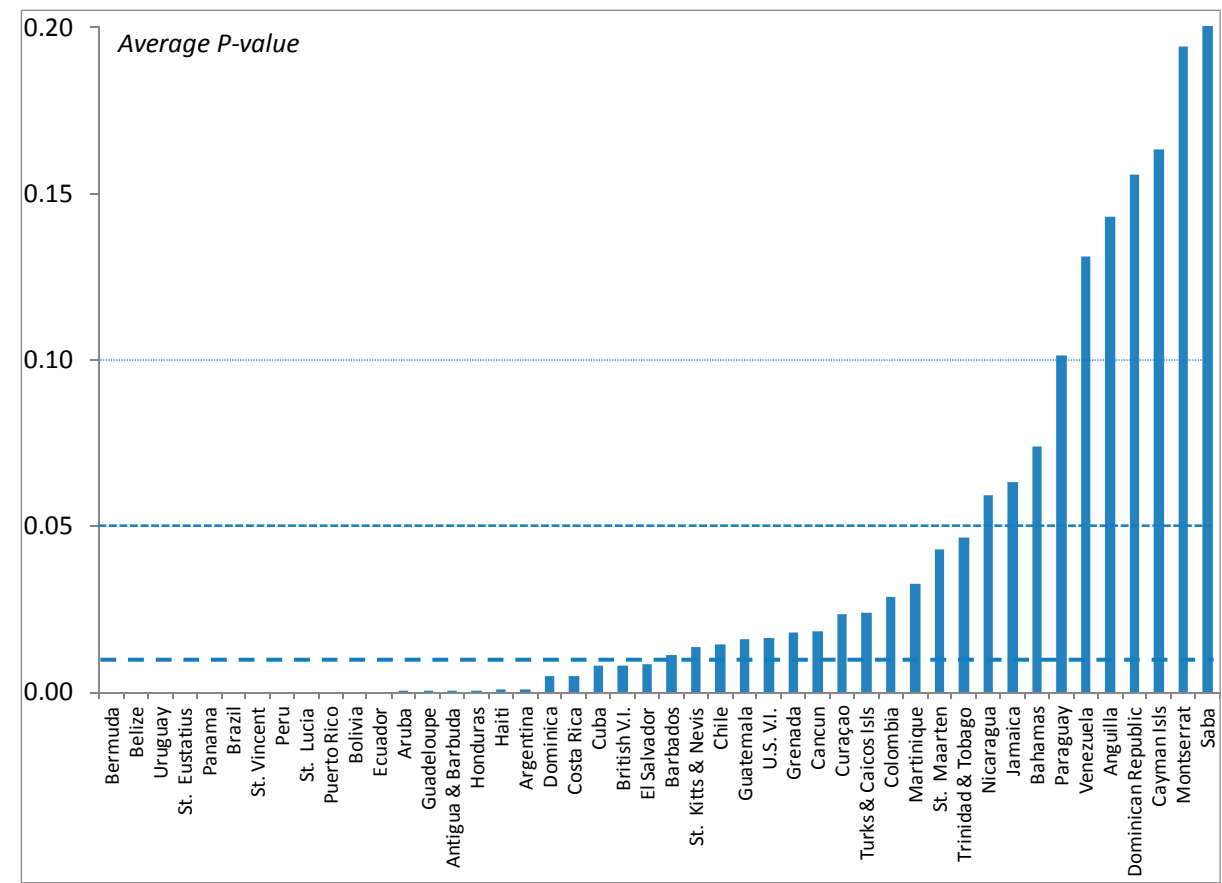

Source: Authors' estimates.

Note: The bars are the average of the MacKinnon approximate $p$-values resulting from Phillips Perron tests for unit roots in the log of tourist arrivals from the destination to all available source countries over the period 1995-2009. The null hypothesis is that the variable contains a unit root, and the alternative is that the variable was generated by a stationary process. The lines indicate three conventional $p$-value levels $(0.1,0.05$, and 0.01$)$. 
Figure 4. OECD Real Wage Changes Against Hotel Price Inflation, 2009

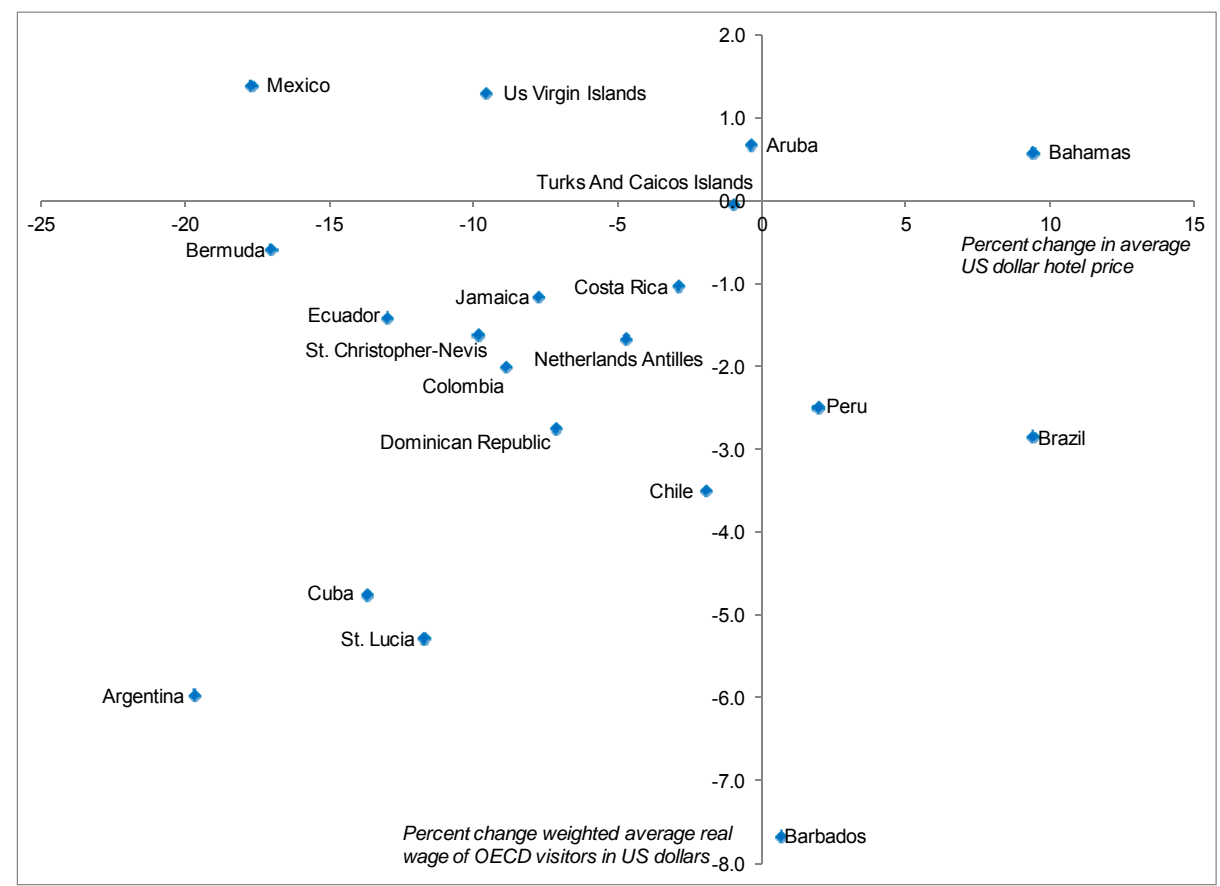

Sources: IMF, Haver Analytics, Hotels.com, ONE Cuba, and author estimates.

Note: The graph compares real (constant prices) wage changes for OECD countries in 2009 in U.S. dollars and averaged using weights based on each OECD country's historical proportion of total arrivals for each Caribbean destination country, with average changes in destination countries' U.S. dollar hotel prices in 2009. Cuba hotel prices are indirectly estimated, all others are observed. 
Figure 5. Arrivals from U.S. and Close Relatives to Cuba, 1990-2009

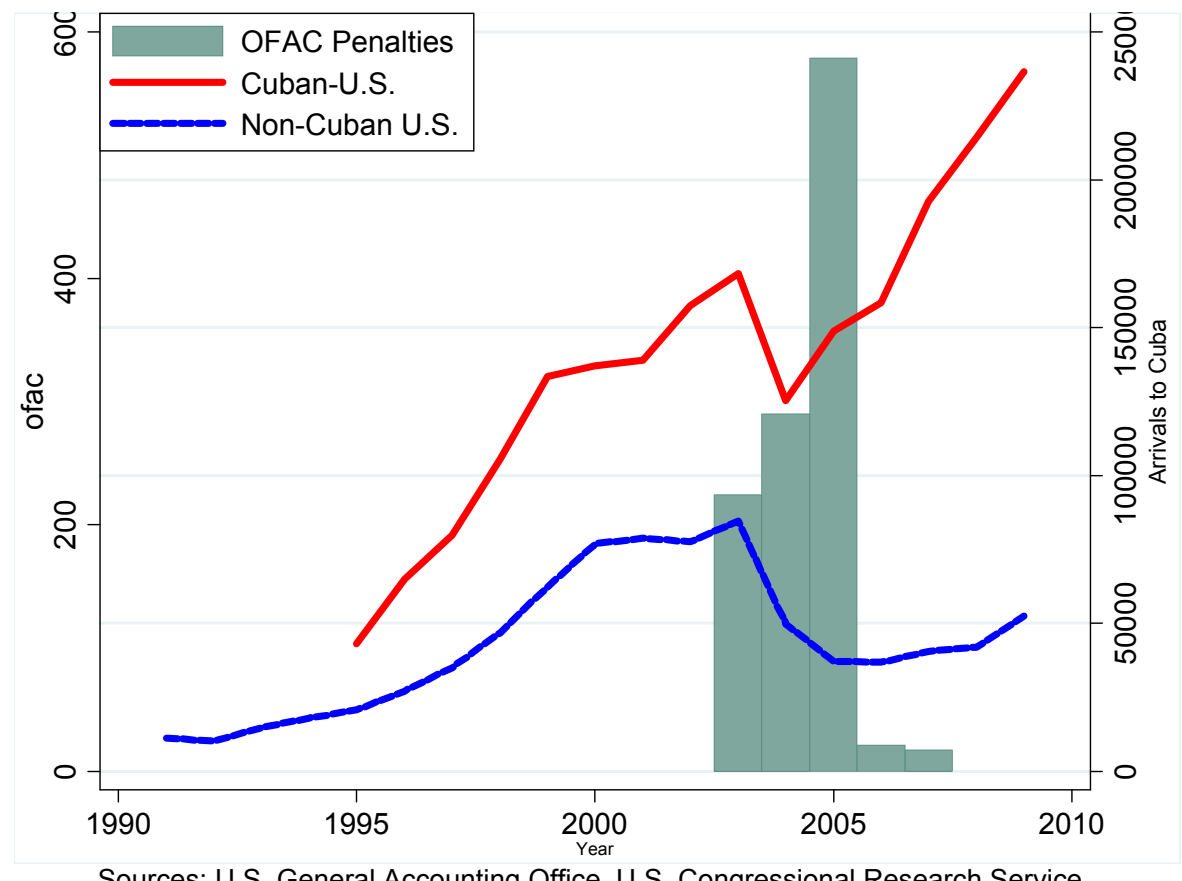

Sources: U.S. General Accounting Office, U.S. Congressional Research Service, WTO.

Note: The graph superimposes the number of tourists arriving from the U.S. to Cuba, both U.S. citizens (blue, right scale) and Cubans residing abroad (persons under U.S. jurisdiction with three degrees of family separation from Cuban citizens, red, right scale) on the estimated number of penalties imposed by the U.S. Office of Foreign Assets Control for Cuba-related travel restriction violations.

Figure 6. Arrivals from Cubans Abroad and the Rest of the World, 2005-09

22

Contribution to growth in arrivals

Cubans abroad

18

14

10

6

$-2$

$-6$

$$
20052006
$$

Rest of World

$$
\text { - Total }
$$

Sources: Cuba National Statistics Office, WTO, and authors' estimates.

Note: The left panel compares the contribution of growth to total arrivals to Cuba from Cubans residing abroad and the rest of the world. The right panel shows the annual growth rate of these two groups and total growth. Total and averages for the period are shown on the right. 
Figure 7. Income Per-Capita of OECD Countries and Cubans
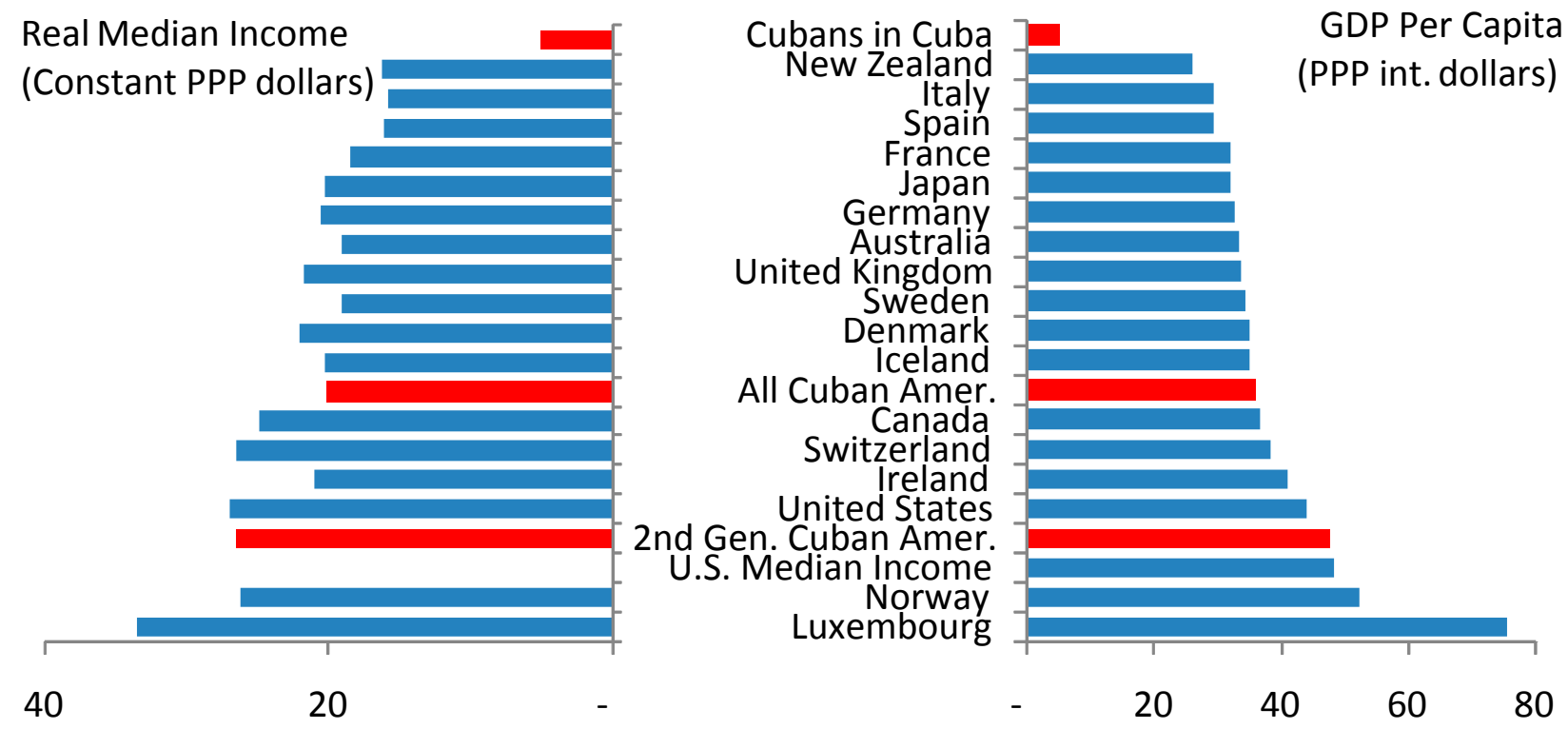

Sources: Di Bella and Wolfe (2009), OECD Stat, Pew Hispanic Center (2006), and World Bank WDI.

Note: In the right panel, GDP per-capita in 2006 international dollars is shown for a sample of OECD countries, as well as median income for Cubans residing in Cuba (based on Di Bella and Wolfe, 2009, red), in the United States, and the second-generation Cuban Americans (both taken from Pew Hispanic Center, 2006, median income, red). Median income is also presented (left panel) based on the OECD figures for the "mid 2000s." For Cubans residing abroad, median income is adjusted to "real" OECD figures in U.S. dollars using the proportional difference between the U.S. Census Bureau median income for the U.S. in 2006 and, based on reporting of the OECD, the "real" U.S. median income for the "mid 2000s" (expressed in their terminology). The GDP per capita figure for Cuba is reported unadjusted in U.S. dollars in both panels. In theory, the left panel provides an "apples to apples" comparison of household income as GDP per capita of Cubans residing abroad is unavailable, but in practice, its cautious interpretation is warranted due to a number of statistical difficulties. For additional comparability, U.S. median income in 2006 is also presented alongside U.S. GDP per capital on the right panel. All figures in thousands. 
Figure 8. Revenue per Tourist, Cuba and Dominican Republic

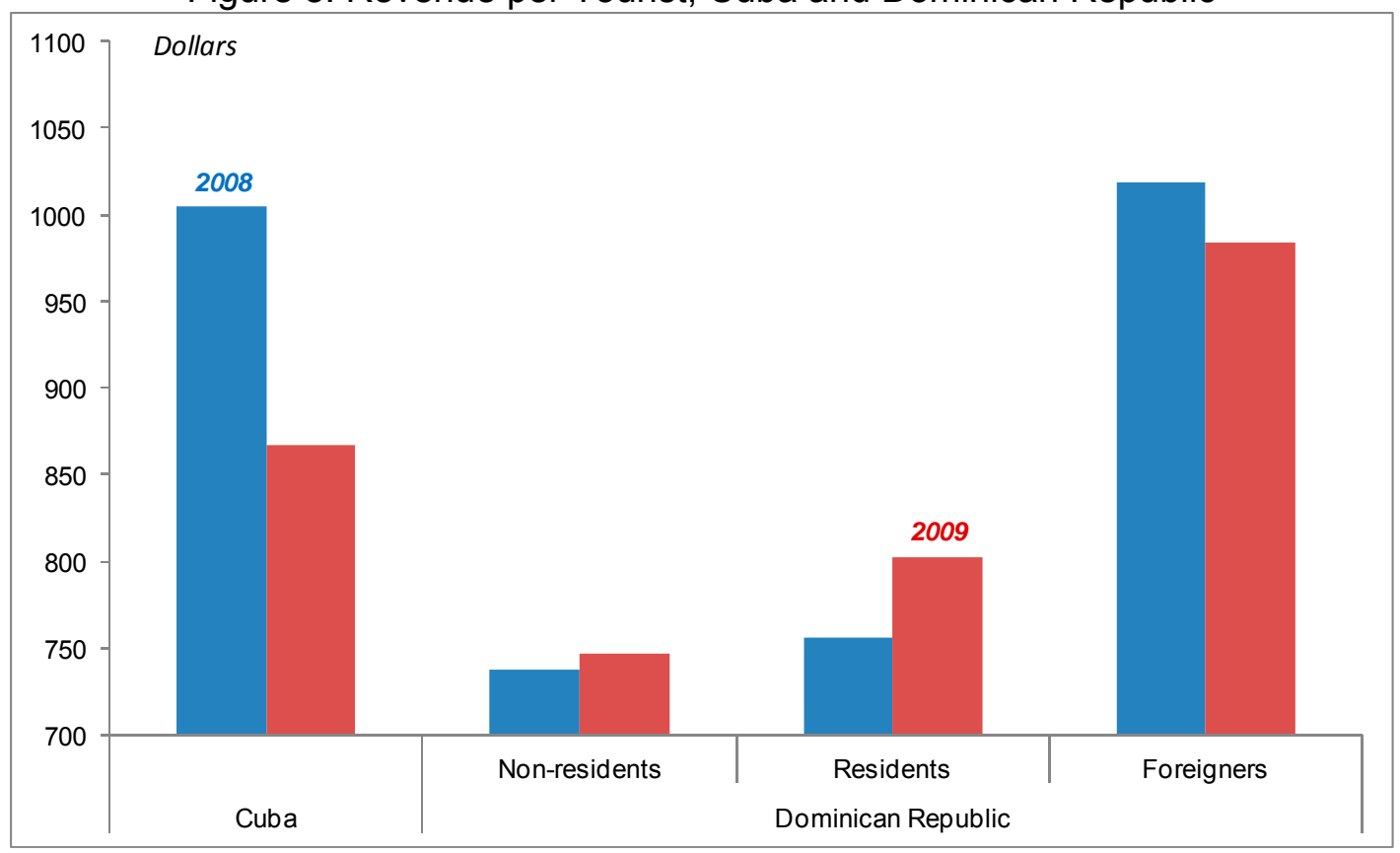

Source: National Statistics Office of Cuba, Central Bank of the Dominican Republic.

Note: The bars represent estimated income by type of tourist for each year. For the Dominican Republic, expenditure is shown for foreigners and both Dominican residents and non-residents. Figures in current dollars at official exchange rates.

Figure 9. Customs Revenue Schedule, Selected Caribbean Countries

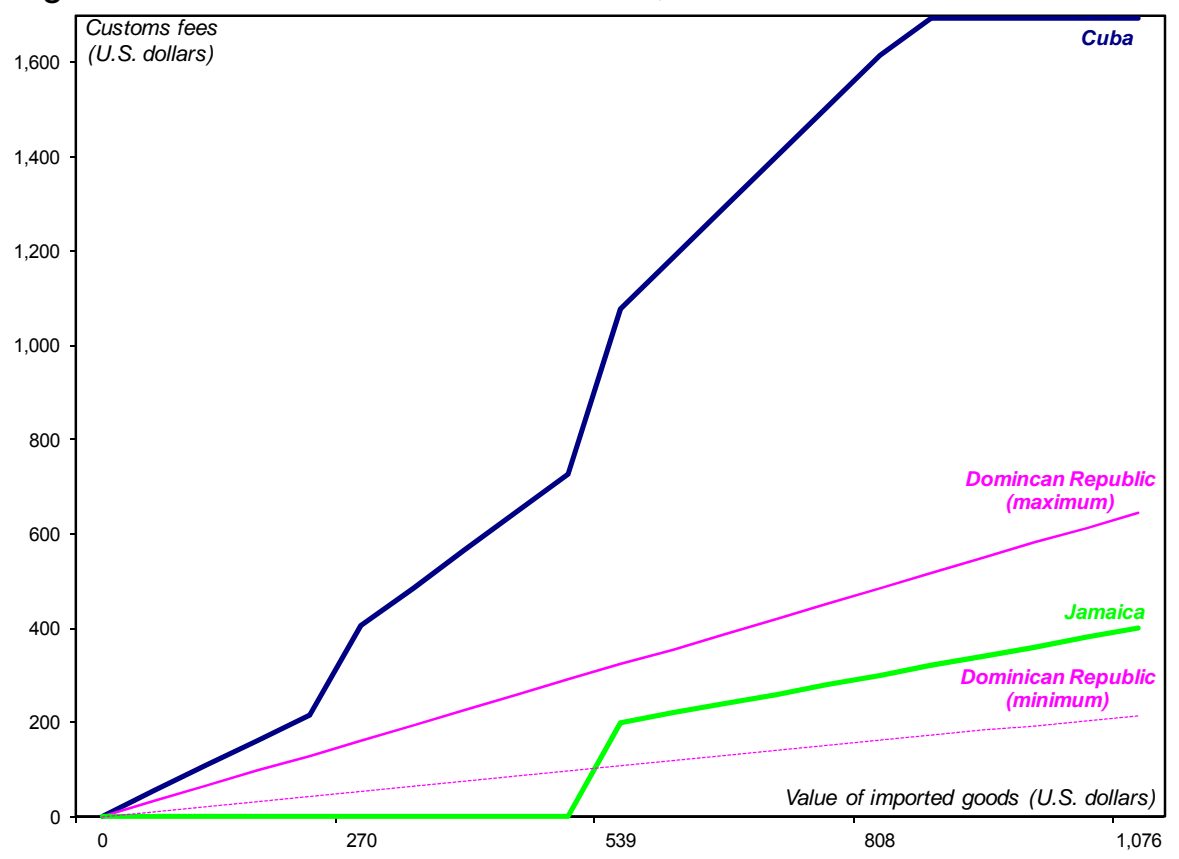

Source: Country authorities.

The graph shows the customs revenue schedule based on the value of imported goods for Cuba, the Dominican Republic, and Jamaica. All values are expressed in current U.S. dollars at official exchange rates, and excludes currency exchange fees. 


\section{REFERENCES}

Anderson, J. and E. van Wincoop, 2003, "Gravity with Gravitas: A Solution to the Border Puzzle,” American Economic Review, Vol. 93, No. 1 (March) pp. 170-92.

Blanchard, O. and N. Kiyotaki, 1987, "Monopolistic Competition and the Effects of Aggregate Demand," American Economic Review, Vol. 77, No. 4 (September) pp. 647-66.

"Cubans in the United States," 2006, Pew Hispanic Center Factsheet (26 August), www.pewhispanic.org.

Diaz-Briquets, Sergio, 2010, "Government Controlled Travel Costs to Cuba and Costs of Related Consular Services: Analysis and International Comparisons," Association for the Study of the Cuban Economy, Cuba in Transition, Volume 20.

— 2001, "Medicare: A Potential Income-Generating Activity for Cuba in the Future," Association for the Study of the Cuban Economy, Cuba in Transition, Volume 11.

Di Bella, G. and A. Wolfe, 2009, "Cuba: Economic Growth and International Linkages Challenges for Measurement and Vulnerabilities in a Bimonetary Economy," in Cuba in Transition, Association for the Study of the Cuban Economy, Volume 19.

Dingel, J., 2009, “The Basics of Dixit-Stiglitz Lite,” Mimeo, Columbia University Economics Department, http://www.columbia.edu/ jid2106/.

Dixit, A. and J. Stiglitz, 1977, "Monopolistic Competition and Optimum Product Diversity," American Economic Review, Vol. 67, No. 3 (June), pp. 297-308.

Henken, T., 2000, "Last Resort or Bridge to the Future? Tourism and Workers in Cuba's Second Economy," Association for the Study of the Cuban Economy, Cuba in Transition, Volume 10.

Padilla, A., 2003, "The Tourism Industry in the Caribbean After Castro," Association for the Study of the Cuban Economy, Cuba in Transition, Volume 13.

Messina, J., C. Strozzi, and J. Turunen, 2008, "Real Wages over the Business Cycle: OECD Evidence from the Time and Frequency Domains," IZA Discussion Papers 3884, Institute for the Study of Labor (IZA).

Romeu, Rafael, 2008. "Vacation Over: Implications for the Caribbean of Opening U.S.-Cuba Tourism,” IMF Working Papers 08/162 (Washington: International Monetary Fund).

Rose, Andrew K., 2004, “Do We Really Know That The WTO Increases Trade?” American Economic Review, Vol. 94 No. 1 (March), pp. 98-114.

Sullivan, Mark P., 2009, “Cuba: US Restrictions on Travel and Remittances,” (March) Congressional Research Service 7-5700, www.crs.gov. 
Sullivan, Mark P., 2007, "Economic Sanctions, Agencies Face Competing Priorities in Enforcing the U.S. Embargo on Cuba," U.S. Government Accountability Office, (November) GAO-08-80.

U.S. Census Bureau, 2006, "Income, Earnings, and Poverty Data From the 2006 American Community Survey," http://www.census.gov/prod/2007pubs/acs-08.pdf. 


\section{ApPEndix I. A FrameWORK fOr ANALysis}

This section outlines a monopolistically competitive market framework based Dixit-Stiglitz preferences. These preferences are employed more generally in Blanchard and Kiyotaki (1987) (henceforth BK) and for trade in Anderson and Van Wincoop (2003) (henceforth, AV). The framework presented here combines the BK framework for the general problem of the consumer with the AV framework for the solution to the monopolistically competitive trade problem faced by tourism destinations. The AV framework is augmented with firmspecific costs that allow a role for distinguishing country-specific effects from shocks external to the tourist destinations. The first section establishes the wider problem of OECD consumers that maximize utility across consumption of tourism services, consumption of all other goods, and disutility of supplying labor. The second section derives the problem of the consumer choosing across different tourism destinations.

\section{A. Macroeconomic Effects}

Consider the problem of $j=1$ to $M$ OECD economies' consumers who derive utility from consuming tourism services across $i=1$ to $N$ Caribbean destinations (the sub-utility function that captures this utility of tourism is denoted $U$ in (1.11)). Consumers also derive utility from consuming a composite basket of all other goods - the numeraire, denoted $G$ in (1.11). Finally, consumers derive disutility form labor, denoted $\mathrm{N}$ in (1.11).

$$
V_{j}=U_{j}^{\gamma} G_{j}^{1-\gamma}-\mathrm{N}_{j}^{\beta}, \quad \text { s.t. } I_{j}-T_{j}-G_{j}=0, \quad I_{j}=W_{j} \mathrm{~N}_{j}+O_{j} .
$$

By assumption, the parameter $\gamma$ is between zero and one, and $\beta$ is equal to or greater than unity. The wage is given by $W_{j}$, and dividend and other incomes are denoted by $O_{j}$. The additive separability of labor disutility allows the level of income to be determined from the tradeoff between labor disutility and the marginal utility of consumption. The optimal consumption problem is solved in two steps. First, consumers allocate income between goods and tourism consumption. Consumers in OECD country $j$ spend $T^{j}$ on all tourism consumption and pay $p_{i j}$ for tourism in destination $i$, out of income $I_{j}$, spending the rest on goods, $G_{j}$. Consumers then maximize the subutility function across tourism destinations which have some imperfect substitutability, given by the elasticity of substitution, $\sigma \equiv 1 /(1-\rho)$ :

$$
U_{j}=\left(\sum_{i=1}^{N} C_{i j}^{\rho}\right)^{1 / \rho} \quad 0<\rho<1, \quad \sigma \equiv 1 /(1-\rho), \quad \text { s.t. } T_{j}-\sum_{i=1}^{N} p_{i j} C_{i j}^{\rho}=0
$$

The tradeoff between consuming tourism and the composite good, labeled $Z_{j}$, is given in (1.13):

$$
Z_{j}=U_{j}^{\gamma} G_{j}^{1-\gamma}, \quad \text { s.t. } I_{j}-T_{j}-G_{j}=0
$$


The share of income allocated across tourism and the composite good that optimizes the Cobb-Douglass preferences in (1.13) is given by $\gamma$, and combined with the solution to the consumer's problem in (1.12) shown below, the solution to can be expressed as:

$$
C_{i j}=\left(\frac{T_{j}}{P_{j}}\right)\left(\frac{p_{i j}}{P_{j}}\right)^{-\sigma}, \text { with } T_{j}=\gamma I_{j}
$$

In (1.14), $\gamma I_{j}$, is optimal level of tourism expenditure by consumers from OECD country $j$, $I_{j}$ is the consumer's income, while $P_{j}$ is the tourism price index faced by consumers in $j$, derived below, and which is a geometric average with weighting parameter $\sigma$ (the elasticity of substitution) of all destination prices. Similarly, the goods allocation of income is given by:

$$
\begin{gathered}
G_{j}=(1-\gamma) I_{j} \cdot(1.15) \\
Z_{j}=\mu I_{j} / P_{j}, \quad \text { with } \mu=\gamma^{\gamma}(1-\gamma)^{1-\gamma} .
\end{gathered}
$$

The assumption that utility is linearly homogeneous in goods and tourism consumption implies that utility is linear in wealth, and thus, in labor income. For the purposes of studying the impact of the recession on tourism, it is sufficient to recognize the wider problem of the household optimization's impact on the expenditure level envelope on all tourism destinations, given shocks in labor income, which are proxied in the estimations by unemployment, consumption and the output gap. BK elaborates this framework in the context of consumption of goods and services and money, to study the impact on the wider economy of monopolistic competition in both goods production by firms and labor supply by households in the presence of wage and price rigidities. The conclusions regarding menu costs that follow from the full BK specification of equilibrium in which firms' price and wage rules, demand functions for the composite good basket and tourism, and the relation between goods and tourism are beyond the scope of the problem presented here.

Recognizing the role of labor income in determining $I_{j}$ alongside equations $(1.14)-(1.16)$ is sufficient to motivate the inclusion of empirical controls for aggregate income changes in the trade regressions. Furthermore, it is assumed that shocks to individual OECD countries' labor income are correlated across OECD groups with similar adjustments in aggregate real wages over the business cycle. Hence:

$$
T_{j}=\gamma I_{j}=\gamma \bar{I}_{g} \hat{I}_{j} \quad \forall j \in g
$$

In (1.17), $\bar{I}_{g}$ represents the common factor driving income for OECD countries in group $g$, while $\hat{I}_{j}$ represents the idiosyncratic component for country $j$.

\section{B. The Problem of the Consumer}

Having characterized the roles of the (non-tourism) consumer good and the labor-leisure and relative consumption results, this section turns to the choice of tourism destination. The amount of tourism expenditure $\left(T_{j}\right)$ that would result from the optimization across 
consumption, money, and leisure given the market structure and potential nominal rigidities in OECD economies is left exogenously determined here to focus on the determinants of tourism demand.

Hence, consumers living in $j=1$ to $M$ OECD economies, given $T_{j}$ tourism expenditure and $p_{i j}$ vacation prices for each consumer-destination pair.

$$
U_{j}=\left(\sum_{i=1}^{N} C_{i j}^{\rho}\right)^{1 / \rho} \quad 0<\rho<1, \quad \sigma \equiv 1 /(1-\rho), \quad \text { s.t. } T_{j}-\sum_{i=1}^{N} p_{i j} C_{i j}^{\rho}=0
$$

The problem of the consumer is reduced to maximizing across destinations which have some imperfect substitutability, with the elasticity of substitution given by $\sigma$.

$$
L=\left(\sum_{i=1}^{N} C_{i j}^{\rho}\right)-\lambda\left(\sum_{i=1}^{N} p_{i j} C_{i j}^{\rho}-T_{j}\right)
$$

The Lagrangian in (1.19) maximizes the monotonic transformation $U^{\rho}$ for simplicity. The first-order conditions yield the following well known ratio:

$$
C_{i j}=\left(\frac{p_{i j}}{p_{i k}}\right)^{-\sigma} C_{i k}
$$

Summing across j's expenditure on all destinations,

$$
C_{k j}=\left(\frac{T_{j} p_{k j}^{-\sigma}}{\sum_{i} p_{i j}^{1-\sigma}}\right)=\left(\frac{T_{j} p_{k}^{-\sigma} t_{k j}^{-\sigma}}{\sum_{i} p_{i j}^{1-\sigma}}\right) \text {, with } p_{k j}=p_{k} t_{k j} .
$$

In (1.21), while the base price for vacationing in destination $k$ is given by $p_{k}$, the final price paid by consumers is marked up by $t_{k j}$ because of travel costs, trade barriers, and other factors to be specified below. Total expenditure by consumers from $\mathrm{j}$ is given by $T_{j}=\sum_{i=1}^{N} p_{i j} C_{i j}^{\rho}$. Income to destination $i$ is defined as $T_{i}=\sum_{j=1}^{M} p_{i j} C_{i j}^{\rho}=\sum_{j=1}^{M} x_{i j}$. A price index faced by consumers for tourism is defined as the geometric average of the destination prices, and given by $P_{j}=\left(\sum_{i} p_{i j}^{1-\sigma}\right)^{1 / 1-\sigma}$, which is analogous to the "multilateral resistance" price index in AV. Demand by consumers can then be expressed as:

$$
C_{i j}=\left(\frac{T_{j}}{P_{j}}\right)\left(\frac{p_{i} t_{i j}}{P_{j}}\right)^{-\sigma}
$$

Substituting the solution to the consumer's problem in (1.22) into the utility in (1.18) yields the expenditure function consistent with the sub-utility function approach necessary to solve BK and implicitly assumed here, $U^{\rho}=\left(T_{j} / P_{j}\right)^{\rho}$. Hence, as OECD unemployment increases, 
lower income per potential tourist consumer lowers tourism expenditure and total tourism consumption (e.g., as would be the case in a Cobb-Douglas utility).

Destination $i$ faces demand given by:

$$
T_{j}=\sum_{j}\left(T_{j} / P_{j}\right)\left(p_{i j} / P_{j}\right)^{-\sigma} p_{i j}=p_{i}^{1-\sigma} \sum_{j}\left(t_{i j} / P_{j}\right)^{1-\sigma} T_{j} \quad \forall i
$$

From (1.23):

$$
p_{i}^{1-\sigma}=\frac{T_{i}}{\sum_{j}\left(t_{i j} / P_{j}\right)^{1-\sigma} T_{j}}
$$

Define the share of OECD tourism expenditure in the region as:

$$
\theta_{j}=T_{j} / \sum_{j} T_{j}=\left(T_{j} / T_{W}\right)
$$

The total tourism from OECD country $j$ to destination $i$ is:

$$
x_{i j}=T_{j} P_{j}^{\sigma-1} p_{i}^{1-\sigma} t_{i j}^{1-\sigma}=\left(\left(T_{j} T_{i} / T_{W}\right) P_{j}^{\sigma-1} t_{i j}^{1-\sigma}\right) /\left(\left(\sum_{j}{ }_{i j} / P_{j}\right)^{1-\sigma}\left(T_{j} / T_{W}\right)\right) \text {. }
$$

Define the cost index for destination $i$ as:

$$
\Pi_{i}=\left(\sum_{j}\left(t_{i j} / P_{j}\right)^{1-\sigma} \theta_{j}\right)^{\frac{1}{1-\sigma}} ;(1.27)
$$

then tourism between OECD country $j$ to destination $i$ can be simplified to:

$$
X_{i j}=\left(T_{j} T_{i} / T_{W}\right)\left(t_{i j} / P_{j} \Pi_{i}\right)^{1-\sigma} .
$$

Using (1.24), the two price indices, $P_{j}$ and $\Pi_{i}$ are shown to be mutually dependant,

$$
P_{j}=\left(\sum_{i}\left(t_{i j} / \Pi_{j}\right)^{1-\sigma} \theta_{i}\right)^{\frac{1}{1-\sigma}} \text { and } \Pi_{i}=\left(\sum_{j}\left(t_{i j} / P_{j}\right)^{1-\sigma} \theta_{j}\right)^{\frac{1}{1-\sigma}}
$$

As in AV, with $t_{i j}=t_{j i}$, then $P_{i}=\Pi_{i}$, and $P_{j}^{1-\sigma}=\sum_{i} P_{i}^{\sigma-1} t_{i j}{ }^{1-\sigma} \theta_{i} \quad \forall j$, and trade is:

$$
X_{i j}=\left(T_{j} T_{i} / T_{W}\right)\left(t_{i j} / P_{j} P_{i}\right)^{1-\sigma}
$$

Through (1.30) the framework reflects the basic conclusions of BK and AV, in that the income effects (left implicit here) and the trade costs will have direct effects on the tourism demand from the OECD to the Caribbean region which will depend on the degree of substitutability between countries.

Fixed and variable production costs can be included in this framework (see for example Dingel (2009)) by assuming each destination faces a tourism cost schedule as a function of the number of visitors that includes a fixed and a variable cost:

$$
\chi\left(C_{i}\right)=f_{i}+m_{i} C_{i}
$$


In (1.31), $f_{i}$ represents the fixed costs, $C_{i}$ is the volume of tourism services as before, and $m_{i}$ the marginal cost per additional tourist. Firms at each destination maximize profits, given by:

$$
\pi_{i}=p_{i} C_{i}-w_{i} m_{i} C_{i}-w_{i} f_{i},
$$

Where $w$ captures the factor cost for destination $i$. The first-order conditions allow the base price at each destination to be expressed as a function of the quantity and the costs,

$$
p_{i}=-C_{i} /\left(\partial C_{i} / \partial p_{i}\right)+m_{i} w_{i} \cdot(1.33)
$$

Using the demand given in (1.21) and assuming a sufficiently large number of tourism firms such that the impact on the price index from a change in one firm's price is negligible, this expression simplifies and yields the familiar result that prices set by monopolistic firms depend on the variable costs and are independent of what others are doing:

$$
p_{i}=\left(m_{i} w_{i} / \rho\right) \text {. }
$$

Combining (1.34) and (1.30) yields the gravity equation,

$$
C_{i j}=\left(T_{j} T_{i} / T_{W}\right) t_{i j}^{-\sigma}\left(P_{j} P_{i}\right)^{\sigma-1}\left(\rho / m_{i} w_{i}\right)
$$

In (1.35), the envelope tourism expenditure for a given OECD destination, given by $T_{j}$, is assumed to follow the income process specified in (1.17), yielding the estimable equation:

$$
C_{i j}=\left(\gamma \bar{I}_{g} \hat{I}_{j} T_{i} / T_{W}\right) t_{i j}^{-\sigma}\left(P_{j} P_{i}\right)^{\sigma-1}\left(\rho / m_{i} w_{i}\right) .
$$

